\title{
STUDIES ON THE CUMACEA (CRUSTACEA, MALACOSTRACA) OF JAPAN. PART III
}

\author{
$\operatorname{AUTHOR}(\mathrm{S}):$ \\ Gamo, Sigeo
}

\section{CITATION:}

Gamo, Sigeo. STUDIES ON THE CUMACEA (CRUSTACEA, MALACOSTRACA) OF JAPAN. PART III. PUBLICATIONS OF THE SETO MARINE BIOLOGICAL LABORATORY 1968, 16(3): 147-192

\section{ISSUE DATE:}

1968-11-20

URL:

http://hdl.handle.net/2433/175545

RIGHT: 


\title{
STUDIES ON THE CUMACEA (CRUSTACEA, MALACOSTRACA) OF JAPAN. PART III.
}

\author{
SIGEO GAMÔ \\ Faculty of Education, Yokohama National University, Yokohama
}

With Plate XVIII and 15 Text-Figures

\section{Contents}

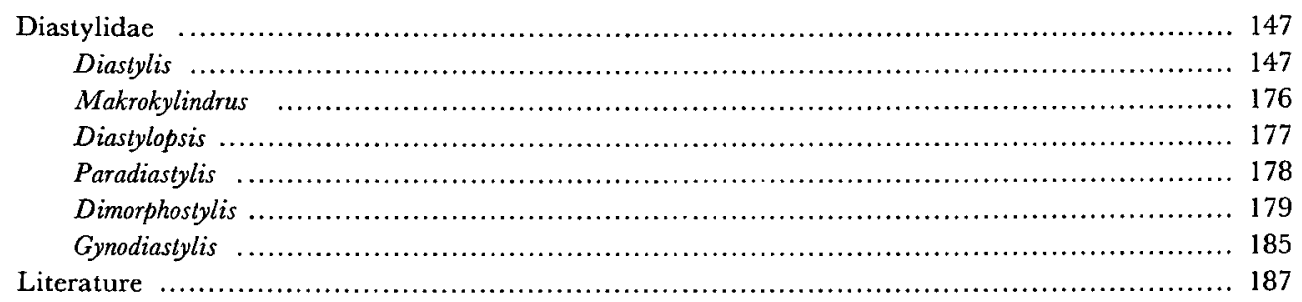

Family Diastylidae Spence Bate, 1856.

Key to genera of Diastylidae

1. Male without pleopods. third maxilliped of female without exopod. First peraeopod with a long brush of setae on the propodus............................... Gynodiastylis

- Male with two pairs of pleopods ….............................................................. 2

2. Third maxilliped of female without exopod........................................ Paradiaslylis

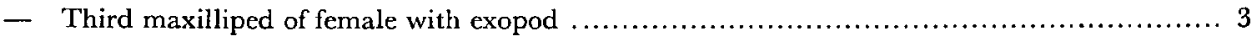

3. Telson comparatively short, without distinct post-anal portion. Third and fourth peraeopod of female quite devoid of exopod...................................... Dimorphosiylis

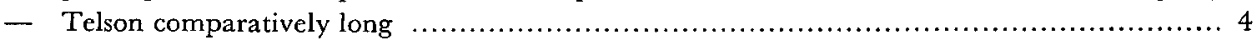

4. Telson much elongated; proximal portion cylindric, post-anal portion not long ......Makrokylindrus

- Telson moderately elongated; post-anal portion long and with lateral spines ................... 5

5. Pleural plates of third and fourth pedigerous somites not much produced backwards; peraeopods 2 and 3 of female not widely separated............................Diastylis

- Pleural plates of third and fourth pedigerous somites well produced backwards; peraeopods 2 and 3 of female widely separated.......................................Diaslylopsis

\section{Genus Diastylis SAY, 1818.}

Key to Japanese species of Diastylis

1. Carapace with ridges or almost entirely smooth and not conspicuously spinulose nor spinose

Publ. Seto Mar. Biol. Lab., XVI (3), 147-192, 1968. (Article 13) 


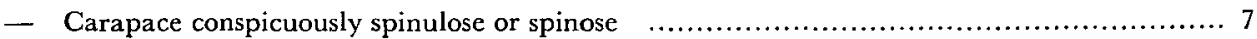

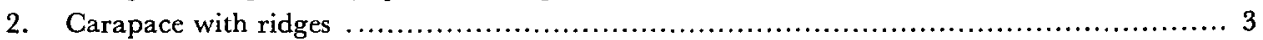

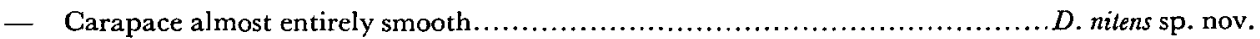

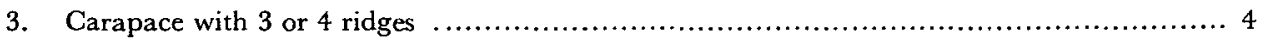

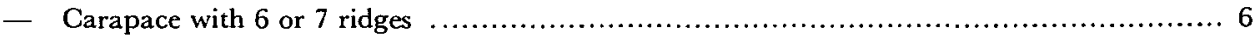

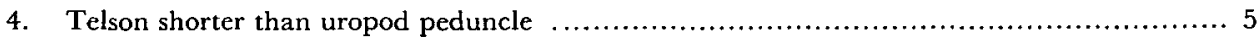

- Telson about as long as ruopod peduncle. Carapace with 4 pairs of oblique

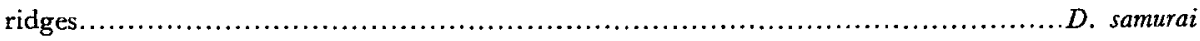

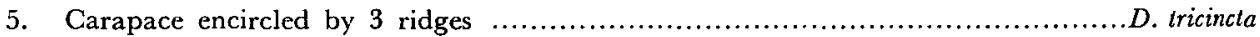

- Carapace with 4 pairs of oblipue ridges........................................... dalli

6. Carapace with 6 ridges. Telson much longer than uropod peduncle ........... D. alaskensis

- Carapace with 7 ridges. Telson about as long as uropod pedundle ............... L. lazarevi

7. Carapace with strong slender spines arranged in a row encircling the anterior region D. utinomii sp. nov.

- Carapace spinulose and without strong spines 8

8. Carapace thickly covered with uniform spinules only. Endopod of uropod with two segments

D. malsuei sp. nov.

- Carapace spinulose and with about six oblique rows of granulated tubercles on each side. Endopod of uropod with three segments D. omorii sp. nov.

\section{Diastylis tricincta (ZIMMER)}

Leptostylis tricincta ZiMmer 1903, p. 691, figs. CC-EE.

Diastylis tricinctus, Zimmer 1908, p. 183; Stebbing 1913, p. 105, fig. 59; Marukawa 1921, p. 857, fig. 2457.

D. tricincla, GAMO 1965c, p. 536, fig. 704.

Male (about $6 \mathrm{~mm}$ ): Body is clear brown. The carapace is narrow, and encircled by three finely denticulate pleats, the formost curving round the frontal lobe and convexed backwards, the second nearer to the third than the fitst. The pseudorostral lobes are horizontal, but not strongly produced; the antero-lateral corners are obsolete.

The fifth free thoracic segment is provided with postero-lateral angles very acutely protruded out and each surmounted with a row of plumose setae.

The first four abdominal segments are provided each with a circle of posteroventral spines; the telson is a little longer than the fifth segment, about $2 / 3$ of the peduncle of the uropod, and furnished with five pairs of lateral spines and a longer apical pair.

The flagellum of the antennule is moderately long.

The exopod of the uropod is slightly shorter than the telson; the endopod is about half as long as the peduncle, and provided with 7,6,13 spines on the medial margin of the segments respectively; spines on the third segment are small; the first segment is rather longer than the third which is a little longer than the second.

Female unknown.

Distribution: Tôkyô Bay (Shinagawa) (Zimmer 1903). 


\section{Diastylis dalli CALMAN}

Diasiylis dalli Calman 1912, p. 605, 635 figs. 40-44; Stebbing 1913, p. 13; Zimmer 1937, p. 43; LomakiNa 1955 a, p. 142 ; 1958a, p. 142; 1958b, p. 145, fig. 83; HARADA 1962, p. 170, figs. 1, 2; Given 1965, p. 224.

The larger animals collected from the Alaskan arctic seas attain 25 or $31 \mathrm{~mm}$ in length (Grven, 1965), while the Japanese specimens, an adult male and a female with developing marsupium described by HARADA (1962), are 11 and $6 \mathrm{~mm}$ long respectively.

Distribution: Off Kushiro, $42^{\circ} 31^{\prime} \mathrm{N}, 144^{\circ} 30^{\prime} \mathrm{E}$, depth $40 \mathrm{~m}$ (CAlman, 1912); off Onagawa, $37^{\circ} 30^{\prime} \mathrm{N}, 149^{\circ} 25^{\prime} \mathrm{E}$, depth $2350 \mathrm{~m}$ (HARAdA, 1962); off Point Burrow (Alaska), depth 33-226 m; Chukotsk Sea, Bering Sea, Sea of Okhotsk, northern part of the Sea of Japan, depth 24-203 m (Zaliv Petra Velikogo, 330-1128 m; Lomakina, 1955).

\section{Diastylis samurai ZIMMER}

(Fig. 22)

Diastylis samurai Zıмmer 1943, p. 133, figs. 1-3.

Male (13 mm long): This species resembles very closely D. bidentata Calman (1912) which has been described from the East Siberian Sea, the Chukotsk Sea, Bering Sea, the Sea of Okhotsk, the northern part of the Sea of Japan and the Pacific coast of North America (Zimmer, 1937; Lomakina, 1958b.)

The carapace is not fully twice as long as the free thoracic segments together. The frontal lobe has three transverse impressed lines which are not carinate as in bidentata; the third line is well marked defining the posterior border of the frontal lobe, in bidentata it is very faintly marked and sometimes quite absent. There are four oblique ridges on each side of the carapace similarly as in bidentata, but they are all rather shorter than those of bidentata. The second ridge is produced, a little away from its lower end, into a strong subacute cornua as in the female of bidentata, the male bidentata has no such a cornua.

The combined length of all the free thoracic segments is a little longer than the abdomen. The dorsal part of the fourth segment is strongly produced backwards in the middle line as in bidentata. The postero-lateral parts of the last segment are each protruded backwards and subacute.

On the underside of the first abdominal segment there is a stout tooth, which follows a faint median carina ending at a small tooth. The second segment has a small protuberance (two median tubercles in bidentata). On the dorsal side of the first segment there are two small dorso-lateral teeth. The telson is twice as long as the last abdominal segment (in Calman's figure of bidentata male, the telson is seemingly $2-1 / 2$ times the last abdominal segment). 
The dactylus of the first peraeopod is stout, subequal in length to the propodus and somewhat longer than the carpus. The carpus of the second peraeopod is up to nearly $1-1 / 2$ times the combined length of the propodus and dactylus; the propodus is about $3 / 5$ of the length of the dactylus.

The peduncle of the uropod is somewhat longer than the telson. The inner border has a rather stout and somewhat curved bristle near the proximal part and many spines on the distal portion. The endopod is about $2 / 3$ of the length of the peduncle and three-segmented, the first is a little longer than the second and its inner border bears many spines. The exopod is a little shorter than the endopod.

Distribution: Off southern coast of Hokkaidô $\left(42^{\circ} 02^{\prime} 40^{\prime \prime} \mathrm{N}, 142^{\circ} 33^{\prime} 20^{\prime \prime} \mathrm{E}\right.$, depth $637-320 \mathrm{~m})$.

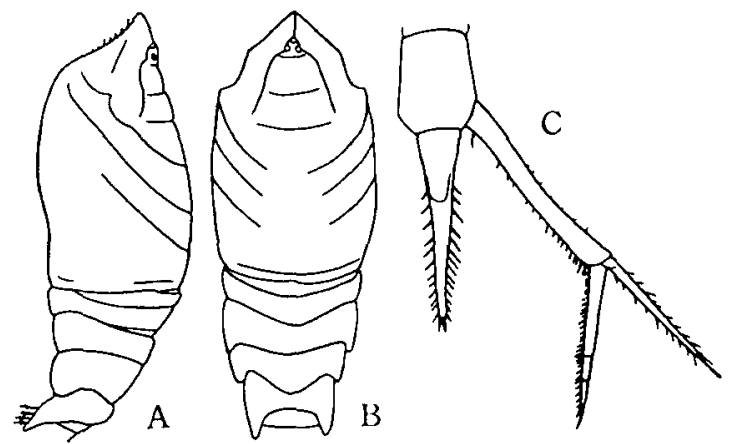

Fig. 22. Diaslylis samurai ZrMmer. Adult male (ca. $13 \mathrm{~mm}$ ). A: carapace and free thoracic segments, lateral side. B: the same, dorsal. D: upropod with the telson and last abdominal segment. (after Zimmer, 1943).

\section{Diastylis alaskensis CALMAN}

Diastylis alaskensis Calman 1912, p. 641, figs. 51-57; Stebbing 1913, p. 93; Zimmer 1937, p. 43; Lomakina 1955a, p. 141; 1955b, p. 125, pl. 27, fig. 1; 1958a, p. 209; 1958b, p. 123, figs. 6, 7; Gamô 1965b, p. 203, figs. 7-9; Given 1965, p. 223.

Mesostylis alaskensis Derzhavin 1926, p. 175, pl. 3, figs. 1-3.

Male $(7.7 \mathrm{~mm})$ and female $(9.3 \mathrm{~mm})$ with well developing marsupium containing about 150 embroys from Akkeshi Bay in Hokkaidô are rather smaller and differ from 13-14 mm long sepcimens described by Calman (1912), Derzhavin (1926) and Lomakina (1958b) in the following points: 1) in the adult male, the carapace is provided with the distinct sixth transverse ridge and its antero-lateral corners are much more rounded and a little more pronounced than in the CalmaN's figure, the sternite of the second to fifth thoracic segments is furnished with a conspicuous median ventral spine and also the first two abdominal segments with a ventral spine, and the first to fifth abdominal segments have respectively a lateral spine at each posteroventral angle. 2) in the adult female, the carapace is much stouter and broader 
than in Calman's and Lomakina's figures and its antero-lateral corners are a little expanded, the peduncle of the uropod is much shorter than in CaLman's specimen.

This species resembles very closely $D$. lazarevi Lomakina, from which it is distinguished by the following characters : both of the two transverse ridges just behind the frontal lobe encircle the carapace almost annularly and the telson has two relatively shorter apical spines.

Distribution: Akkeshi Bay (Hokkaidô); the Chukotsk Sea, the Bering Sea, the Sea of Okhotsk, northern part of the Sea of Japan and the Pacific coast of North America; depth range 8-196 $\mathrm{m}$; in Akkeshi Bay the animals were also collected by a sub-surface haul at night.

\section{Diastylis lazarevi LOMAKINA}

Diastylis lazareri Lomakina 1955a, p. 144, figs. 39-41; 1958b, p. 125, fig. 68; Gamô 1965b, p. 211, figs. 10-11.

Young female $(5.4 \mathrm{~mm})$ and male $(5.5 \mathrm{~mm})$ from Akkeshi Bay are rather smaller and slightly differ from LomakinA's specimens $(6-6.5 \mathrm{~mm}-\$ ; 6 \mathrm{~mm}-\hat{\delta})$ originally described and figured. The differences are attributable to the geographical or age variation. The species is closely allied to $D$. alaskensis, from which it is distinguished by the uropod armature and the pattern of the transverse ridges on the carapace.

Distribution: Akkeshi Bay (Hokkaidô); the estuary of the Amur (the Sea of Okhotsk).

\section{Diastylis nitens sp. nov.}

(Figs. 23-25)

Diastylis sp. (D), GAMÔ 1967b, p. 23, pl. 1, fig. 5.

Holotype: An adult ovigerous female (length, about $9.1 \mathrm{~mm}$ ) with about 39 embryos in the marsupium (embyos about $0.32 \mathrm{~mm}$ in diameter). The carapace is rather robust, almost fusiform in dorsal view and the surface is very smooth and glossy in appearance, except that it bears minute sparse hairs and two pairs of spinules on the frontal lobe and five or six spinules on the antero-lateral sides.

The length of the carapace is three-eighths of the body length exclusive of the telson and more than 1-1/2 of the width which is much greater than the depth. The pseudorostrum is forizontally projected forward in front of the carapace, about four times as long as the ocular lobe and nearly one-fifth of the carapace length. The pseudorostral lobes meet together in front of the ocular lobe, and bear a spinule on each distal end and a shallow longitudinal groove along the middle line. The ocular lobe is very small, oval in shape and without discernible ocelli. The antennal notch is slightly concave. The antero-lateral and lateral or lower borders of the carapace are serrate. 
The length of the free thoracic segments together is a little less than two-eighths of the body length. The depth or height of the segments is successively decreased posteriorly. The second segment is the widest, the last three segments are successively narrowed towards the rear. The side plates of the last four segments are rather prominent. The third segment is partly ankylosed in the posterior dorso-lateral parts with the foruth.

The abdomen is a little less than one-half of the body length. The first three segments are almost of the same size, the fourth is a little longer than each of the preceding segments. The fifth sagment is the longest, about one and one-fourth times the length of the fourth. The sixth segment is about three-fourths as long as the fifth and furnished with spinules along the posterior margin.

The peduncle of the left antennule is a little shorter than the distal two segments together, the second segment is a little longer than the third. The main flagellum bears two segments and a segment-like protuberance, it bears two subequal long aesthetascs. The accessory flagellum is rather large, about half as long as the main flagellum, and three-segmented; the first and third segments are very short. The right antennule is rather in a defective state.

The antenna is rudimentary and bears five segments.

The mandible bears twelve plumose spines on the right and nine similar spines and a lacinia mobilis on the left side.

The maxillula and maxilla are shown in Fig. 24, E and F.

The branchial apparatus of the first maxilliped bears eleven lobules and one accessory one.

The second maxilliped bears eight filaments and five rudimentary ones on the coxal segment (Fig. 24, H).

The basis of the third maxilliped is rather slender and a little robust towards the distal end. The external angle is a little projected as a broad lobe with long plumose hairs. The inner angle bears a spine. The length of the basis, measured along the middle line of the segment, is one and five-sixths times as long as the remaining distal segments together.

The basis of the first peraeopod is slender, a little narrowed towards the distal end, five-sevenths as long as the remaining distal segments together, and furnished with plumose hairs on both lateral borders. The dactylus is slightly shorter than the propodus which are subequal to the carpus in length.

The second peraeopod is longer than one-half of the first. The basis is rather slender, a little shorter than the remaining distal segments together, and furnished with three stout spines on the inner angle. The inner border bears plumose hairs. The carpus is a little shorter than the propodus and dactylus combined. The dactylus is twice as long as the propodus and provided with long setae, of wihch the distal one is very prominent, much longer than the dactylus itself.

The bases of the third and fourth peraeopods are cylindrical in shape and bear 


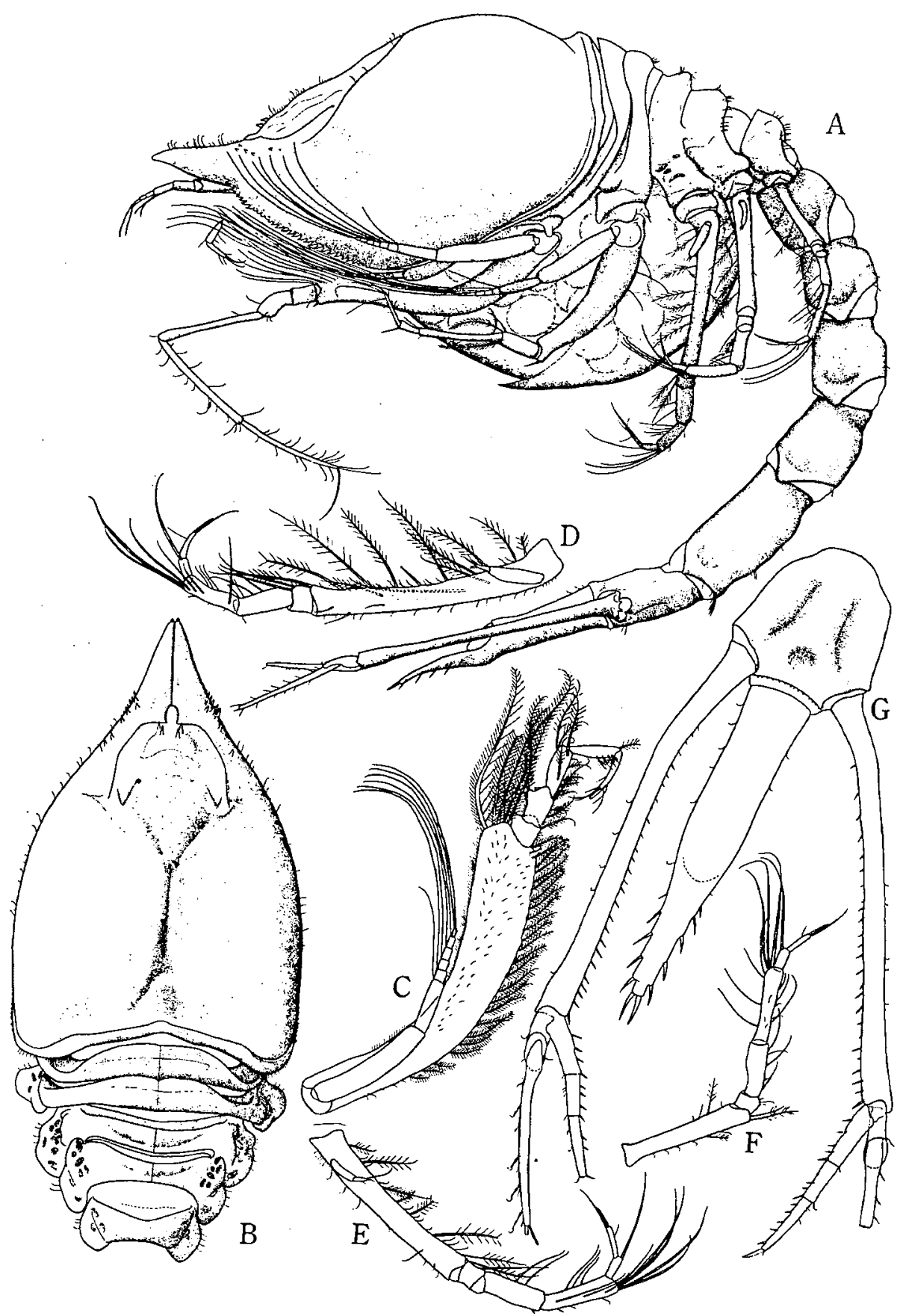

Fig. 23. Diastylis nitens sp. nov., holotype ovigerous female $(9.1 \mathrm{~mm})$. A: lateral view. B: anterior portion of body, dorsal. C: third maxilliped. D-F : third to fifth peraeopods. $\mathrm{G}$ : uropods with telson and last abdominal segment. 
each a rudimentary exopod which consists of only two segments, rather long peduncular segment and small distal one with setae. The third peraeopods is four-fifths as long as the second and the fourth is a little shorter than the third. The fifth peraeopod is nearly four-fifths the length of the fourth. The basis of the third peraeopod is one and one-third times the length of the remaining distal segments together, while in the fourth the basis is nearly as long as the distal segments together.

The telson is about two and one-fourth times the length of the last abdominal segment, the post-anal portion is a little shorter than the pre-anal portion and bears five pairs of lateral spines and a pair of apical spines.

The peduncle of the uropod is nearly one and one-fourth times the length of the telson and bears 26 spines on the inner border ( 27 on the right side). The right exopod is nearly one and one-fourth times as long as the left endopod and provided with five spines on the outer border and two spines at the distal end. The endopod is threesegmented, respectively provided with $5,4,5$ and one apical spine; the first and third segments are subequal in length; the second segment is short, about two-thirds as long as the first one.

Paratype: A juvenile male $7.2 \mathrm{~mm}$ long and very like the ovigerous female holotype in general appearance. However, the carapace is somewhat oval in shape as seen from above, without spinules on either side of the base of the pseudorostrum, and with only a pair of spinules posterior to the ocular lobe. The carapace length is more than one-third the body lentgh (exclusive of telson), about one and two-thirds times the width which is greatest arcoss the middle portion and a little larger than the depth.

The length of the free thoracic segments together is a little less than one-half of the carapace length. The third segment is the widest. The side plates of the last four segments are rather prominent.

The abdomen is a little shorter than one-half of the body and bears two pairs of rudimentary pleopods on the first two segments. The first four segments are approximately of the same size. The fifth segment is the longest, about 1-1/2 times the length of the fourth or sixth segment. The sixth segment is furnished with spinules along the posterior border.

The first segment of the peduncle of the antennule is about as long as the distal two segments combined. The second segment is a little longer than the third. The main flagellum is slightly longer than the third peduncular segment and provided with three segments, a segment-like protuberance and two aesthetascs.

The mandibles bear eleven plumose spines on the right and eight spines and a lacinia mobilis on the left side.

The respiratory apparatus of the first maxilliped has about 20 lobules and one accessory one.

The basis of the third maxilliped is a little shorter than twice the remaining distal segments together and bears one spine at the inner distal angle. 


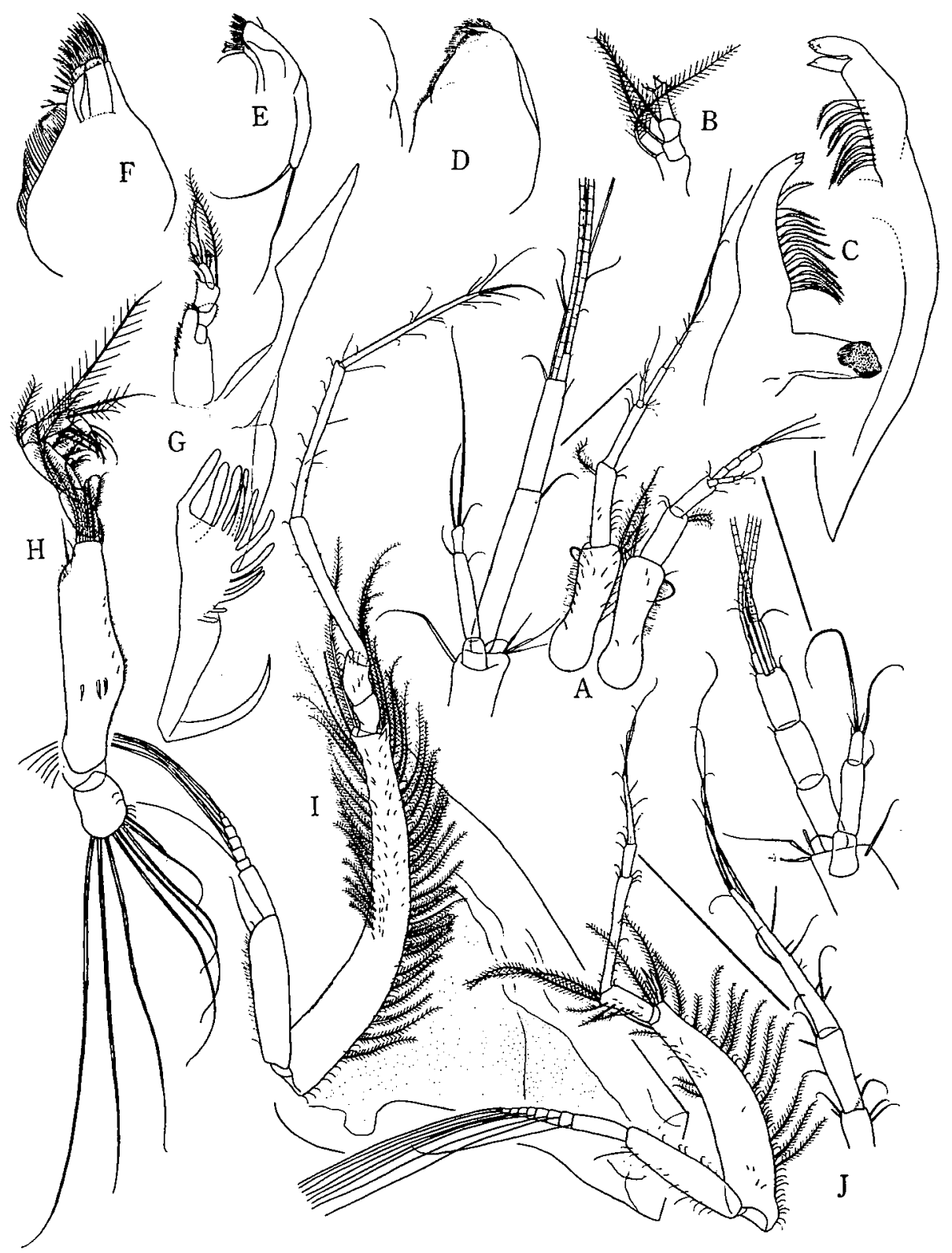

Fig. 24. Diastylis nitens sp. nov., holotype ovigerous female. A: antennule. B: antenna. C: mandibles. D: labium. E-F: maxillula and maxilla. G-H: fitst and second maxillipeds. I-J: first and second peraeopods. 


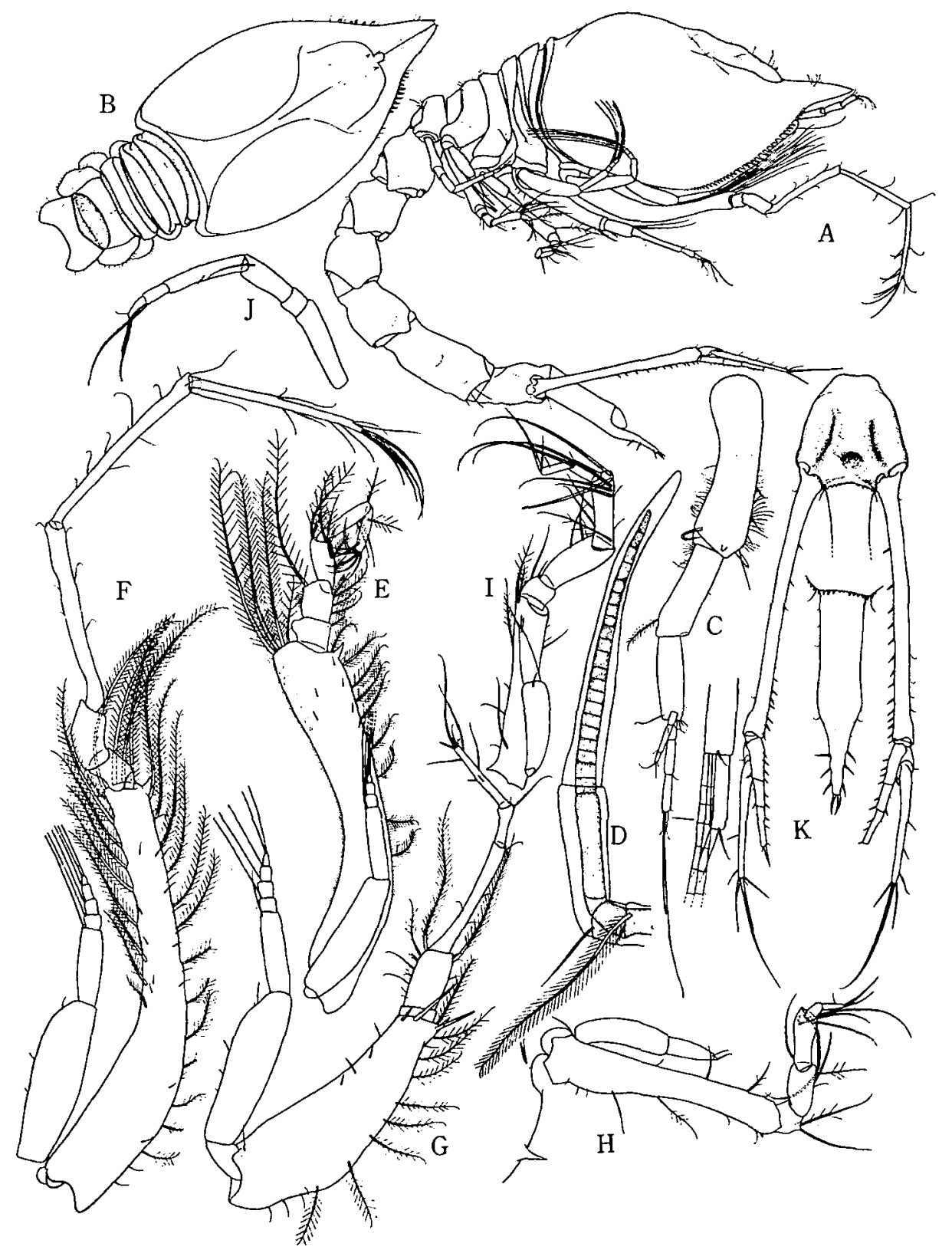

Fig. 25. Diastylis nitens sp. nov., paratype juvenile male $(7.2 \mathrm{~mm})$. A: lateral view. B: anterior portion of body, dorsal. C: antennule. D: antenna. E: third maxilliped. F-J: first to fifth peraeopods. $\mathrm{K}$ : uropods with telson and last abdominal segment. 
The basis of the first peraeopod is two-thirds as long as the remaining distal segments together and bears two spines on the distal portion. The dactylus is a little shorter than the propodus which is as long as the carpus.

The second peraeopod is about one-half as long as the first. The basis, a little stouter than in female, is about four-fifths as long as the remaining distal segments together, and bears four slender spines on the distal portion. The carpus is slightly shorter than the propodus and dactylus combined. The dactylus is one and twothirds of the length of the propodus and bears long setae, including some longer than the dactylus.

The third and fourth peraeopods, each with an exopod, are subequal in length and a little longer than two-thirds of the second. The basis of the third is $1-1 / 2$ times the length of the distal segments together, whereas that of the fourth is a little shorter than the distal segments together. The fifth peraeopod is three-foruths as long as the fourth and the basis is nearly one-half as long as the distal segments together.

The telson is one and three-fourths as long as the sixth abdominal segment; the post-anal portion is a little shorter than a half of the telson length, a little shorter than the pre-anal portion, and bears three pairs of lateral spines and a pair of apical spines.

The peduncle of the uropod is one and one-third times the telson length, two and one-third times the length of the last abdominal segment, and furnished with fourteen spines on the inner border. The endopod is two-fifths as long as the peduncle, three-segmented; the first and third segments are subequal in length; spines on three segments are 4, 2, 3 and 1 apical spine respectively, The exopod is 1-1/4 times the length of the endopod and provided with two to three setae on the outer border and three apical spines, one of which is very long.

Material: 1 o ovigerous (holotype); 9 o with marsupium and 1 o juvenile (para-

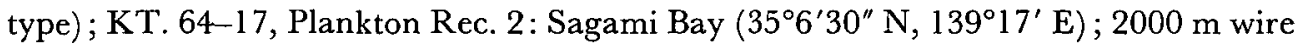
out; maximum depth about $1000 \mathrm{~m}$, collected by oblique tow of ORI-net (Ocean Research Institutie-net, for macroplankton); 25 October, 1964 (Time: 16.34-17.45); coll. Dr. M. ÓmORI.

Remarks: The new species very closely resembles $D$. rathkei (KRÖYER) and $D$. glabra (ZIMmer) (STEBbing, 1913; ZIMMER, 1926 and 1930,) but it can be distinguished from those in the following points: the telson is longer than the uropodal peduncle, in the fifth free thoracic segment the post-lateral angles are not strongly produced backwards to from an acute process, and the third and foruth peraeopods are each provided with a rudimentary exoped.

\section{Diastylis omorii sp. nov.}

(Figs. 26-28)

Diastylis sp. (C), Gamô 1967b, p. 23, pl. 1, fig. 4.

Holotype: An adult female (12.2 mm long, exclusive of telson) with well developed marsupium containing 49 embryos, each about $0.65 \times 0.5 \mathrm{~mm}$ in diameter. 
The carapace is much raised postero-dorsally as seen from the side, globose in shape as seen from above, and furnished with six oblique rows of rather large tubercles on each side. The carapace is almost covered with minute spines and sparse short hairs on a reticulated surface (Fig. 26, C). On the frontal lobe there are a pair of submedian longitudinal rows of spinules, leaving the median portion between them free from

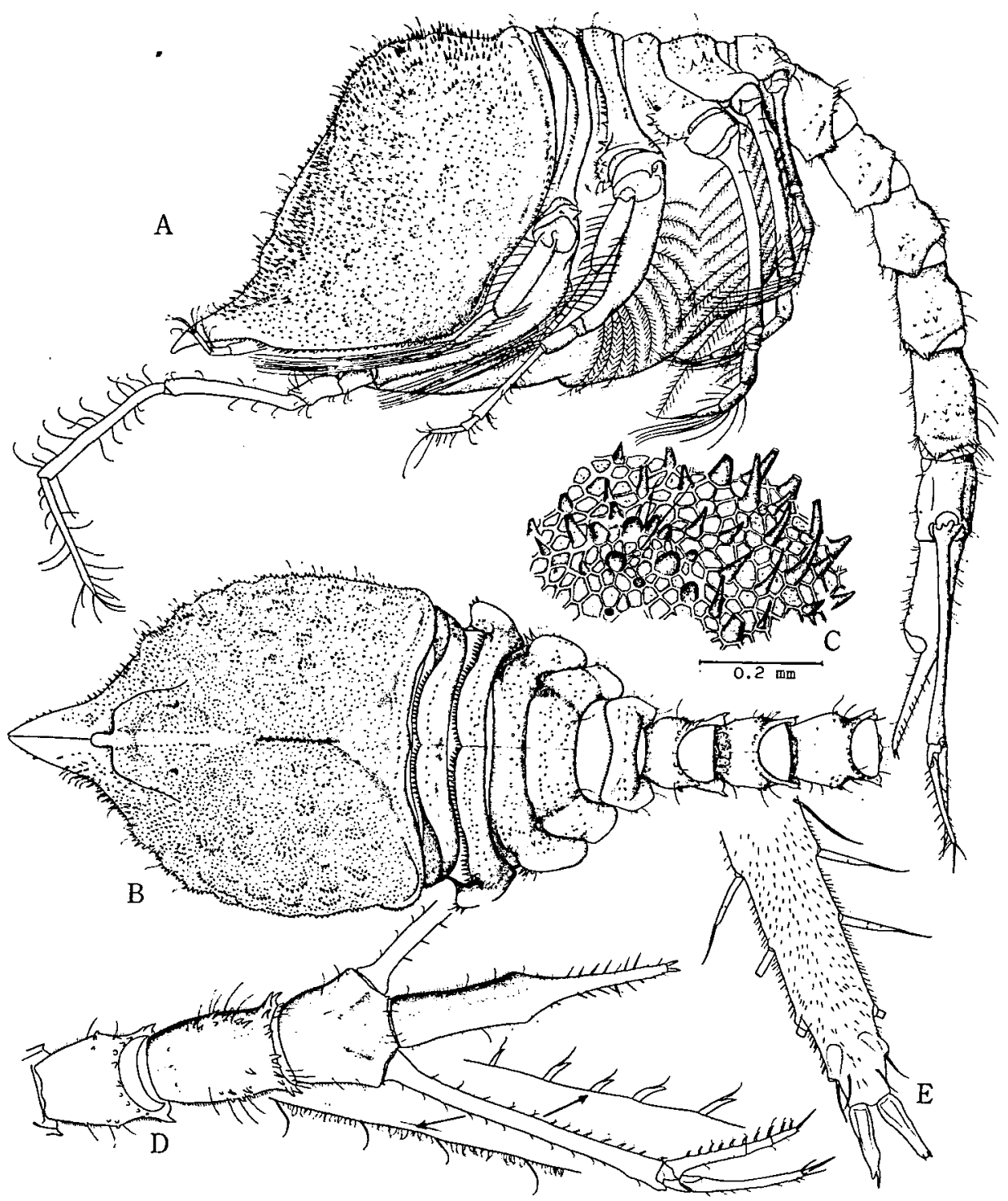

Fig. 26. Diastylis omorii sp. nov., holotype ovigerous female $(12.2 \mathrm{~mm})$. A: lateral view. B: anterior portion of body, dorsal. C: texture of carapace surface. D: uropod with telson and last three abdominal segments. E: distal portion of telson. 
spinules. Posterior to the frontal lobe the carapace bears a very narrow longitudinal dorso-median groove which is flanked by the much inflated branchial regions. The carapace length is nearly two-fifths as long as the body and about three-fourths of the width. The greatest width is seen across about the anterior one-third of the carapace and about four-fifths of the depth. The ocular lobe is very small, digitiform in shape and without discernible ocelli. The antennal notch is shallowly sinuated and bears serrations. The lower or lateral margin is also furnished with serrations. The pseudorosturm is horizontally projedted out in front of the carapace and about one-sixth as long as the carapace; its apical portion is somewhat bent downward.

The surface of the free thoracic segments is furnished with sparse hairs and spiniform granules and spines. The anterior margin of the first, second and fifth segments is furnished with conspicuous serrations. The side plates are rather prominent and provided with spines. The length of the free thoracic segments together is about onefifth of the animal length. The segments are successively decreased in height or depth posteriorly.

The second segment is the widest, a little narrower than the carapace and the last four segments are successively narrowed towards the rear.

The abdomen is much shorter than a half of the body length. Every segment is furnished with sparse hairs and spines on the lateral side and also along the posterior border. The postero-lateral angle of the articular process of the segment is emphasized by a rather stout spine. The first four segments are approximately of the same size and the fifth segment is a little longer than the fourth. The sixth segment is about three-fourths as long as the fifth and furnished with several small spiniform granules on the ventral surface and also along the posterior margin.

The first segment of the peduncle of the antennule is about one and one-fifth times the combined length of the subequal distal two segments. The main flagellum, nearly as long as the third peduncular segment, bears three segments; the first segment is short; the third segment is slightly shorter than the second and bears a segment-like protuberance and two long aesthetascs. The accessory flagellum is about one-third as long as the main lash and three-segmented.

The antenna is shown in Fig. 27, B.

The manidibles bear 17 plumose spines on the right and 14 similar spines and a lacinia mobilis on the left side.

The maxillula and maxilla are shown in Fig. 27, F and G.

The respiratory apparatus of the first maxilliped is provided with 20 lobules and an accessory one.

The second maxilliped bears 11 filaments and 7 rudimentary ones on the coxal segment.

The basis of the third maxilliped is two and one-fifth times the length of the remaining distal segments together and a little robust towards the distal end, the inner border with plumose hairs and the external border with fine hairs. The distal inner 


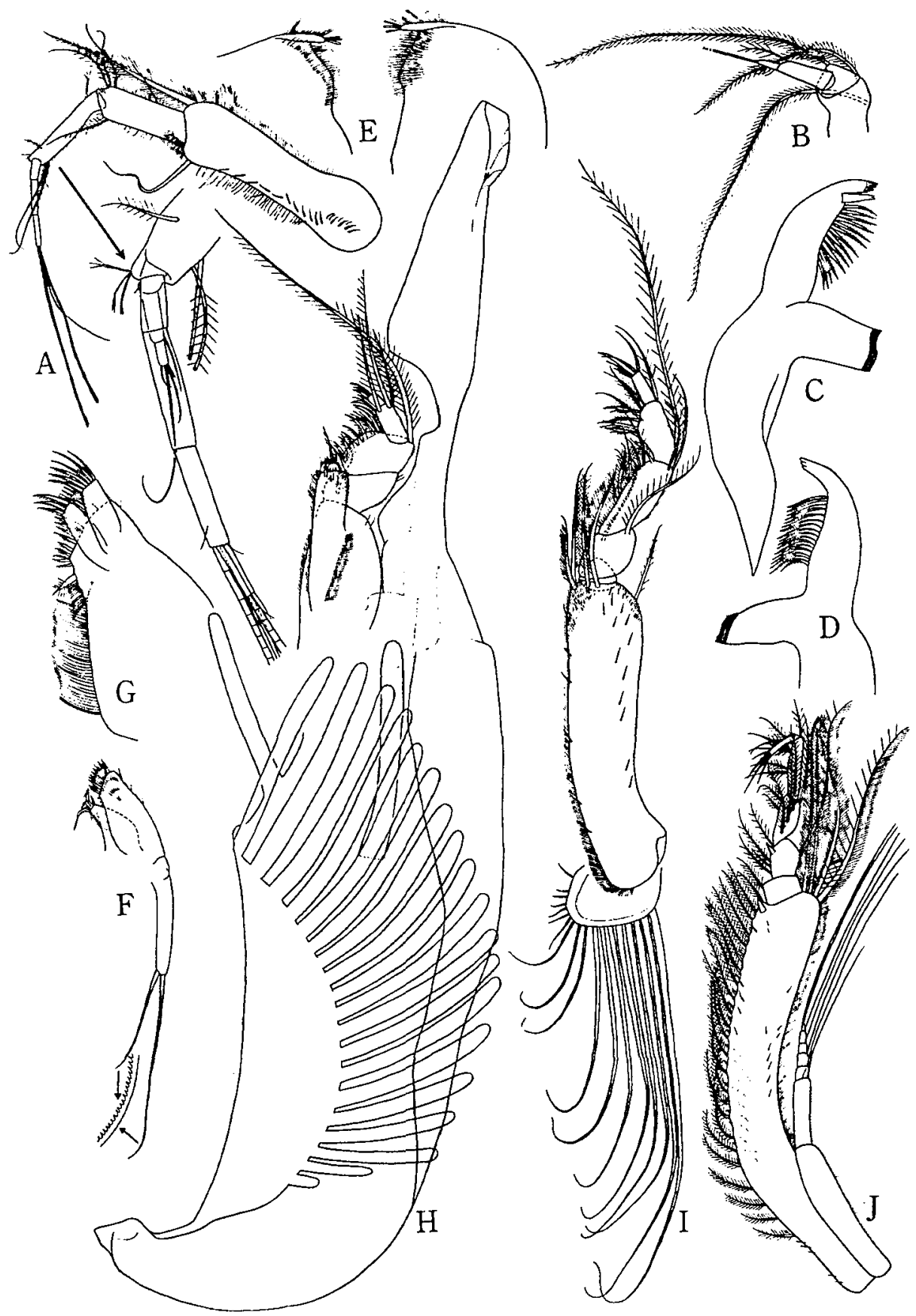

Fig. 27. Diaslylis omorii sp. nov., holotype ovigerous female. A: antennule. B: antenna. G-D: mandibles. E: labium. F-G: maxillula and maxilla. H-J: first to third maxillipeds. 
angle of the basis and merus is provided with a spine.

The basis of the first peraeopod is slender, slightly narrowed distally and threefifths as long as the remaining distal segments together, and provided with two spines at the distal inner angle and a little spinose and setose on the ventral surface. The propodus is nearly one and one-sixth times as long as the carpus. The dactylus is three-fourths as long as the propodus.

The second peraeopod is a little shorter than one-half of the first. The basis is rather slender, six-sevenths as long as the remaining distal segments together, and bears long plumose hairs on both lateral sides and several short setae on the ventral surface. The carpus is one and two-thirds as long as the propodus and dactylus together. The dactylus is about twice as long as the propodus and bears apical plumose setae which are nearly as long as the dactylus itself.

The third peraeopod is shorter than the second and a little longer than the fourth. The bases of the third and fourth peraeopods bear each the rudimentary exopod which is a knob-like tubercle with short setae. The basis of the third peraeopod is much longer than the remaining distal segments together, while that of the fourth is about as long as the distal segments together. The fifth peraeopod is much shorter than the fourth and its basis is much shorter than its distal segments together.

The telson is two and one-half times the length of the last abdominal segment and covered with short setules. The pre-anal portion, about half as long as the telson, is hairy and bears small tubercles on the ventral surface. The post-anal portion is provided with eight pairs of lateral spines and a pair of apical spines.

The peduncle of the uropod is a little longer than the telson and furnished with fourteen spines on the inner border. The rami are slightly shorter than the peduncle. The endopod is three-segmented; the first segment is longer than the distal two subequal segments combined; spines on the segments are 6,2,2+1 apical respectively.

Material: 1 o ovigerous (holotype) and 3 i subadult (paratype); KT 64-17, Plankton Rec. -2 ; Sagami Bay $\left(35^{\circ} 6^{\prime} 30^{\prime \prime} \mathrm{N}, 139^{\circ} 17^{\prime} \mathrm{E}\right)$; $2000 \mathrm{~m}$ wire out, maximum depth, about $1000 \mathrm{~m}$; collected by oblique tow of ORI-net (Ocean Reserarch Institute-net for macroplankton); 25 October, 1964 (Time: 16.34-17.45); coll. Dr. M. ÔMORI.

Remarks: This spcies bears some resemblance to $D$. helleri ZIMmer from the Antarctic seas (Zimmer, 1909; Stebing, 1913; Calman. 1918), D. koreana Calman from Korea, Kamchatka, Zaliv Petra Velikogo and Vancouver (Calman, 1911; Stebbing, 1913; Har'T, 1930; Lomakina, 1958b), and D. aspera Calman from Kodiak, the Bering Sea, the Sea of Okhotsk, and Sakhalin (Calman, 1912; Stebrinc, 1913; Lomakina, 1958b), but it differs from them in the following respects: the endopod of $D$. helleri is provided with only one segment, the antennular peduncle of $D$. koreana has the first and third segments subequal to each other and respectively longer than the second, and the carapace of $D$. aspera bears the more or less prominent ridges instead of the rows of tubercular granules. 


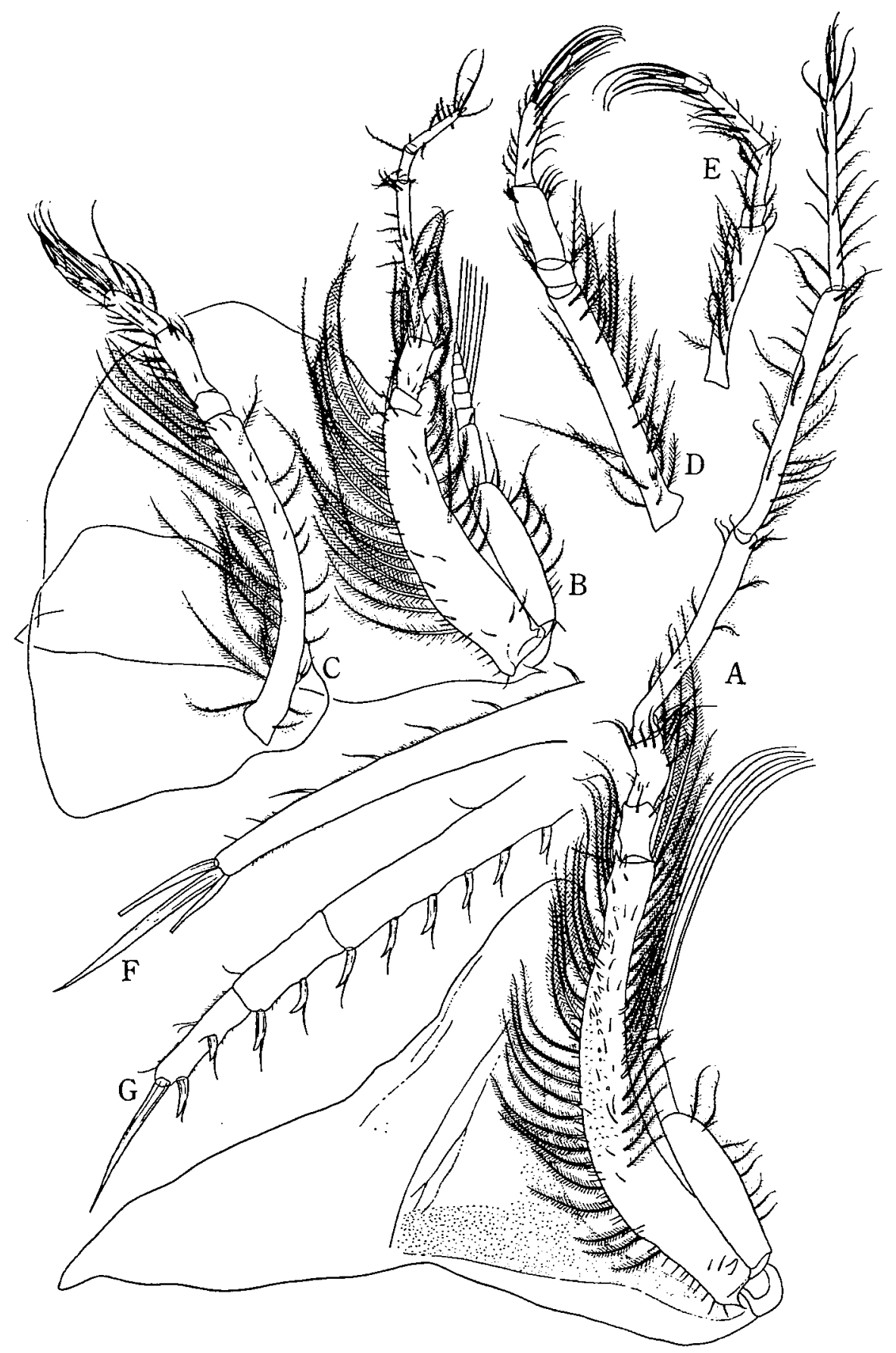

Fig. 28. Diastylis omorii sp. nov., holotype ovigerous female. A-E: first to fifth peraeopods. F-G: exo- and endopod of uropod. 


\section{Diastylis utinomii sp. nov.}

(Figs. 29-32)

Diastylis sp. (A), GaMô 1967b, p. 22, pl. 2, fig. 14.

Holotype: A female with rudimentary marsupium (13.6 $\mathrm{mm}$ long). The sculpture on the carapace surface and free thoracic and abdominal segments is shown in Fig. 29, C. In the dorsal aspect the carapace is somewhat slender and gradually narrowed towards both ends, and the pseudorostrum is pronouncedly tapered. The carapace length is a little less than two-fifths of the body length and about one and one-third times the width which is greatest across the middle portion and nearly one and a half times the depth. The carapace is covered with minute spinules and sparse hairs, and ornamented around the antero-dorsal portion with large slender spines arranged in circles. On each basal side of the pseudorostrum there are three or four slender spines. The frontal lobe is divided into three main humps by two shallow transverse depressions, the first two humps each with a pair of spines and the third with three or four spines. The dorso-median groove is narrow, rather deep and flanked by the swollen branchial regions on both sides. The antennal notch is obscure, sinuated very shallowly, and provided with slender ieeth. The antero-lateral and lower margin of the carapace is conspicuously serrated. The ocular lobe is rather large, semicircular in shape, and without discernible ocelli. The pseudorostrum is long, about one-fourth as long as the carapace, and horizontally projected forwards.

The total length of the free thoracic segments is nearly one-fifth as long as the animal. The first segment is rather short and narrow. The second segment is furnished with fine serrations on the anterior margin. The third segment is the widest and dorsally fused with the fourth. The fourth segment is the longest as measured along the dorso-median line. The dorsum of the segments is spinulose and the side-plate is rather prominent and with spinules. In the first three segments there are one or two transverse rows of small spines on the dorsum. The posterior part of the side-plate of the fifth segment is rounded, a little protruded backwards and berars a samll spine.

The abdomen is less than a half of the animal length. The surface of the segments is spinulose, especially conspicuously on the dorsum. There are two strong spines on the ventral surface of the first segment. The posterior dorsal margin of the first four segments is provided with a pair of long plumose setae and small spines, of which the submedian two are longer and stouter than the others. The second to fourth segments are slightly smaller than the first and approximately of the same size. The fifth segment is the longest, a little longer than the fourth or the sixth. The sixth segment has spinules on the postero-dorsal margin.

The first segment of the antennular peduncle is about four-fifths as long as the distal two segments combined and provided with four strong spines on the ventral surface. The second segment is slender, three-fourths as long as the first and less than twice as long as the third segment which is also slender and covered with fine 


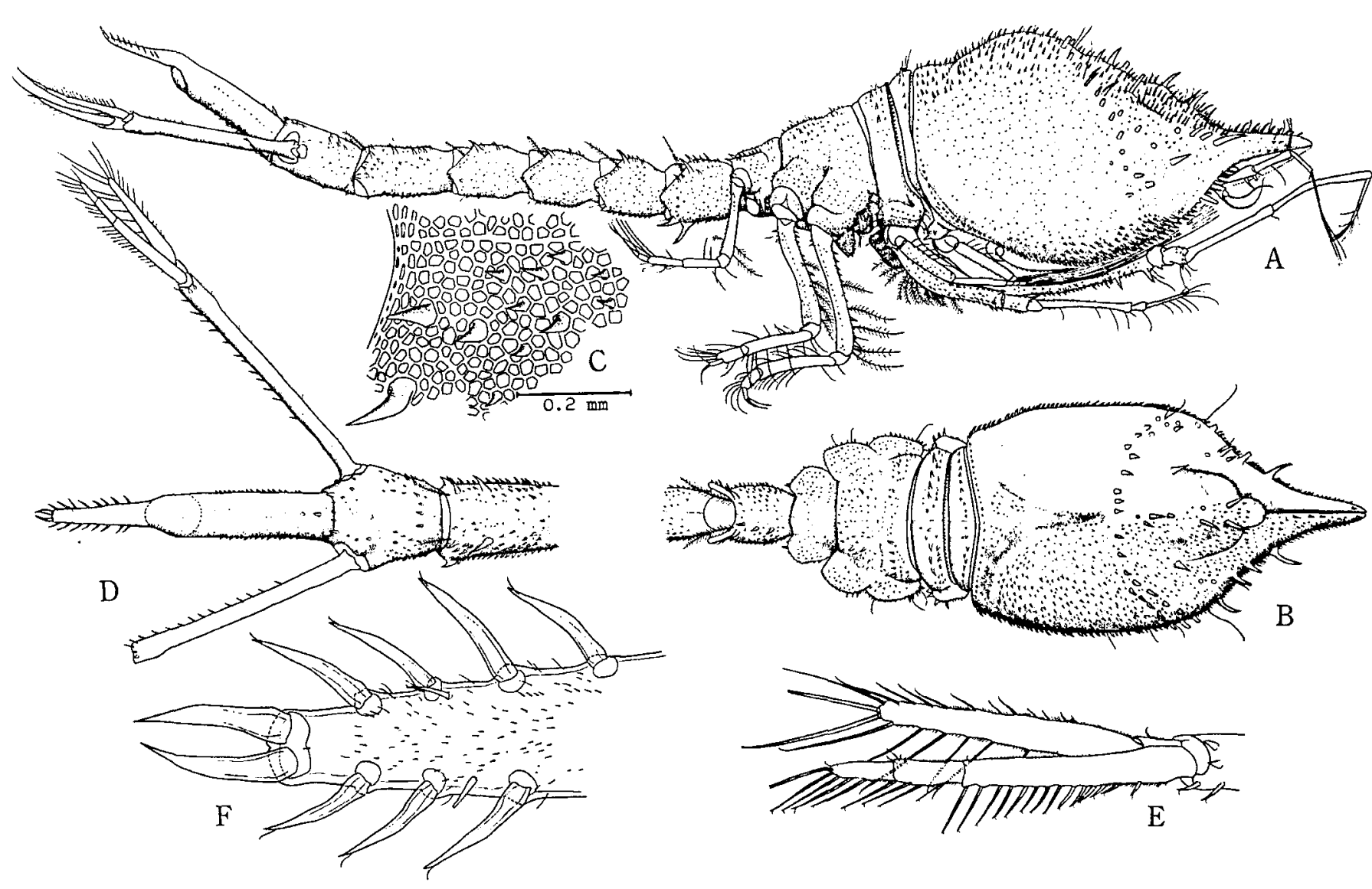

Fig. 29. Diaslylis utinomii sp. nov., holotype female with rudimentary marsupium $(13.6 \mathrm{~mm})$. A: lateral view. B: anterior portion of body, dorsal (spinules of left side of carapace omitted). C: sculpture of carapace surface. D: uropods with telson and last two abdominal segments. E: exo- and endopod of left uropod. F: distal portion of telson. 
setules. The main flagellum is long, much longer than the third peduncular segment and three-segmented; the second flageller segment is much longer than the first which is subequal to the third in length; the third segment beasr a small segment-like protuberance and two long aesthetascs. The accessory flagellum is about one-fourth of the length of the main lash and bears three segments; the first and third segments are very short and subequal in length, whereas the second is very long.

The antenna is rudimentary, though rather large (Fig. 30, B).

The mandible bears 19 plumose spines on the right and 20 similar spines and a lacinia mobilis on the left side.

The first maxilliped bears 14 lobules and an accessory one on the branchial apparatus.

The second maxilliped is shown in Fig. 30, G.

The basis of the third maxilliped is shorter than twice the remaining distal segments together and furnished with strong spines and plumose hairs on the inner border. The ischium and merus are also provided with strong spines on the distal portion. The carpus bears serrations on the inner border. The propodus is rather slender, longer than the carpus. The dactylus is about two-thirds as long as the propodus.

The basis of the first peraeopod is a little shorter than three-fourths of the remaining distal segments together and furnished with strong spines and fine spinules on the disial part of the ventral surface and plumose hairs on both lateral borders. The ischium and merus with stout spines on the distal portion. The dactylus is slightly longer than a half of the propodus which is as long as the carpus.

The second peraeopod is three-fifths as long as the first. The basis is longer by one-fifth than the remaining distal segments together, and bears small spines on the ventral surface and strong spines in a row and plumose hairs along the lateral borders. Both the ischium and merus are furnished with spines. The surface of the carpus, propodus and dactylus is covered with fine setulae. The carpus is a little shorter than two distal segments combined and furnished with spinules on the proximal portion and with two spinules near the distal end. The dactylus is two-fifths as long as the carpus and a little more than twice the propodus and bears long setae, of which the distal two or three are about as long as the dactylus itself.

The third peraeopod is five-sixths as long as the second and a little longer than the fourth. The basis of the third and fourth peraeopods is without any sign of rudimentary exopod. The basis of the third peraeopod is nearly as long as the remaining distal segments together, while that of the fourth is much shorter than the distal segments together. The fifth peraeopod is two-thirds as long as the fourth and its basis is nearly three-fourths as long as the remaining distal segments together.

The telson is two and half times the last abdominal segment. The pre-anal protion is cylindrical, about two-thirds as long as the tselon itself and provided with two small spines on the dorsal surface of the proximal portion, 15 or 17 small teeth on 


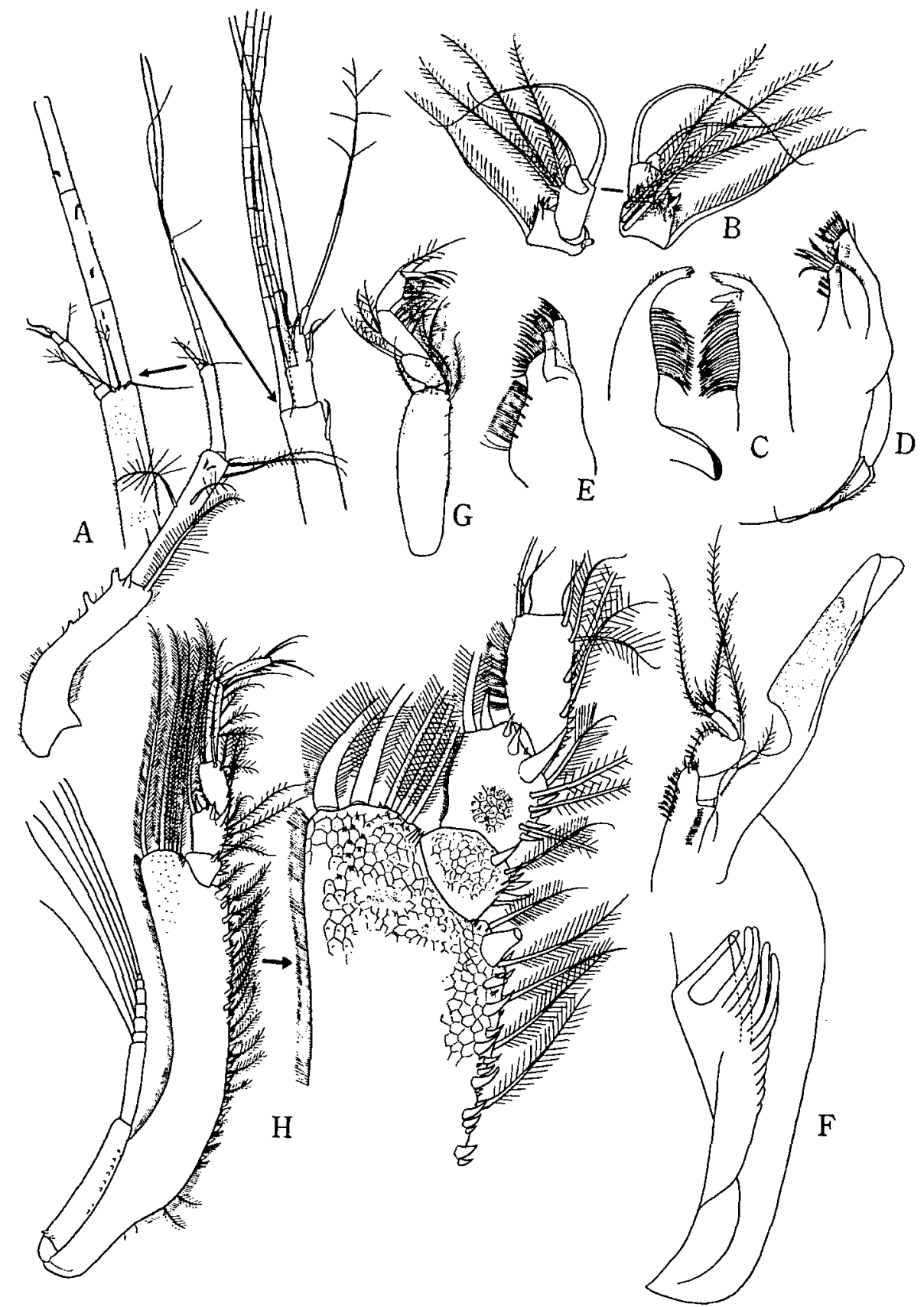

Fig. 30. Diastylis utinomii sp. nov., holotype female with rudimentary marsupium. A: antennule. B: antenna. $\mathrm{C}$ : madibles. D-E: maxillula and maxilla. F-H: first to third maxillipeds. 
both lateral sides, and eleven teeth on the ventral surface of the middle portion. The post-anal portion bears eight pairs of lateral spines and a pair of apical spines.

The peduncle of the uropod is a little shorter than the telson and bears 13 (left) or 14 (right) spines on the inner border and two on the postero-dorsal margin. The exopod is nearly one-half as long as the peduncle, and bears six long setae on the inner, two long and ten short setae on the outer border and two long setae at the apex. The endopod is a little longer than the exopod and three-segmented; the first segment is long, nearly twice as long as the distal two subequal segments combined, and its inner border with 14 setae which decrease the length posteriorly; the distal two segments with $4,5+1$ (apical) setae respectively, the length of the lateral setae successively becomes shorter posteriorly.

Paratype: A young male $(12.5 \mathrm{~mm}$ long). The general appearence of the paratype male is very like the holotype female. The carapace length is slightly less than two-thirds of the body length and longer by about two-thirds than the width which is greatest across about the anterior one-third where it is nearly equal to the depth. The pseudorostrum is slightly shorter than in the female, one-fifth as long as the carapace.

The total length of the free thoracic segments is about one-fifth of the body length. The segmentation between the third and fourth segments is well marked.

The abdomen is a little less than a half of the animal length and provided with two pairs of pleopods on the first two segments. The first segment bears strong spines on the ventral surface.

The first segment of the antennular peduncle is a little shorter than the distal two segments combined and furnished with two rows of spines on the ventral surface. The second segment is a little longer than one and half times the first and beras four spines on the outer side of the proximal portion. The distal portion of the third segment is abruptly narrowed distally. The main flagellum has five segments, a small segment-like protuberance and two long aesthetascs; the proximal two segments are very short, whereas the distal three are much longer and subequal in length. The accessory flagellum is about one-third as long as the main lash and four-segmented; the first and fourth segments are very short, the third is the longest.

The antenna is not yet fully developed, barely reaching the posterior margin of the fifth free thoracic segment (Fig. 32, D).

The mandible bears 20 plumose spines on the right and 21 similar spines and a lacinia mobilis on the left side.

The first maxilliped is provided with 17 lobules, an accessory one and 47 rudimentary ones on the branchial apparatus.

The basis of the first peraeopod is less than two-thirds of the total length of the remaining distal segments. The spines on the basis, ischium and merus are rather stronger and a little more than in the female. The carpus is armed with spinules on both sides of the proximal portion. Both the propodus and carpus are much slender 


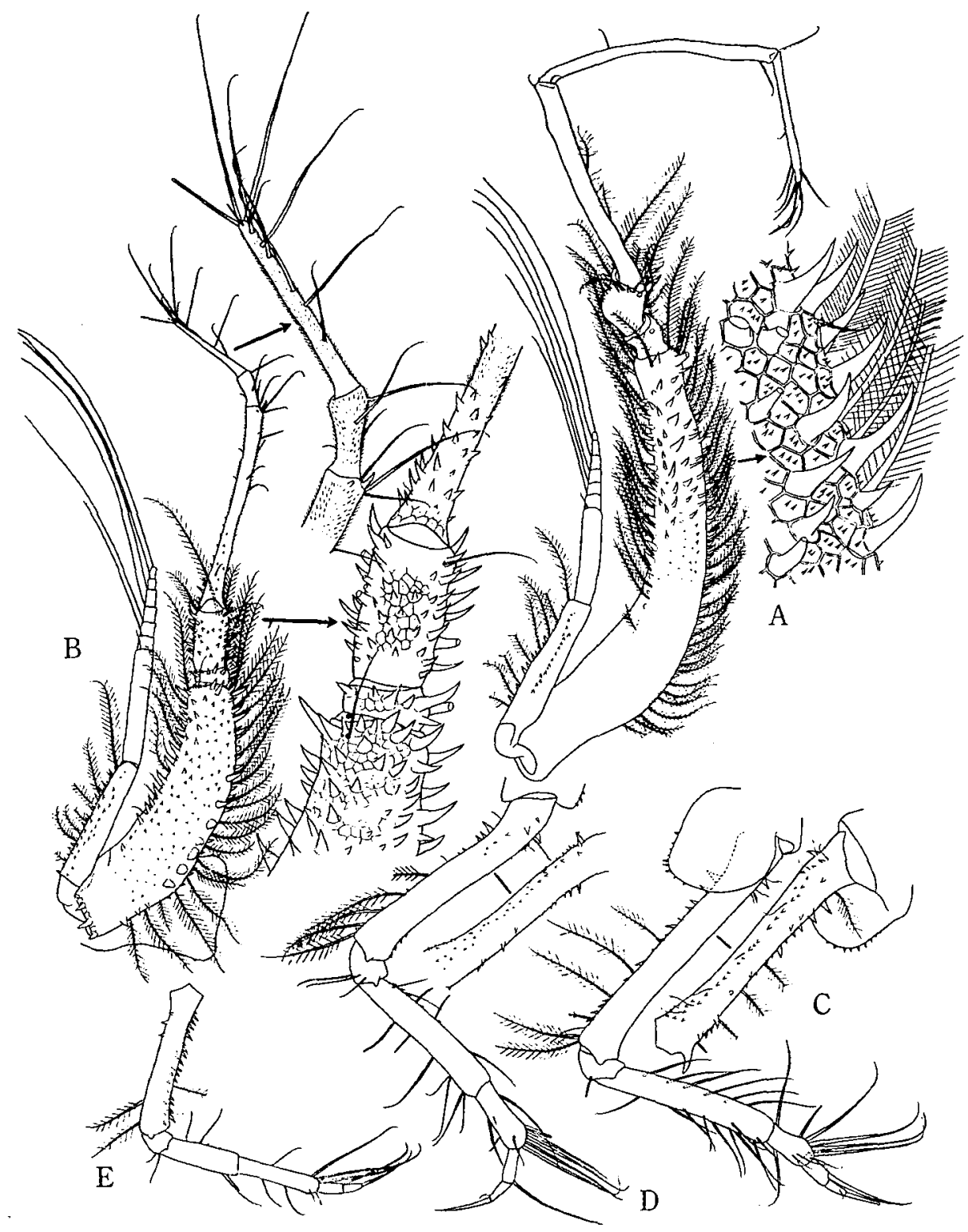

Fig. 31. Diastylis ulinomii sp. nov., holotype female with rudimentary marsupium. A-E: first to fifth peracopods. 


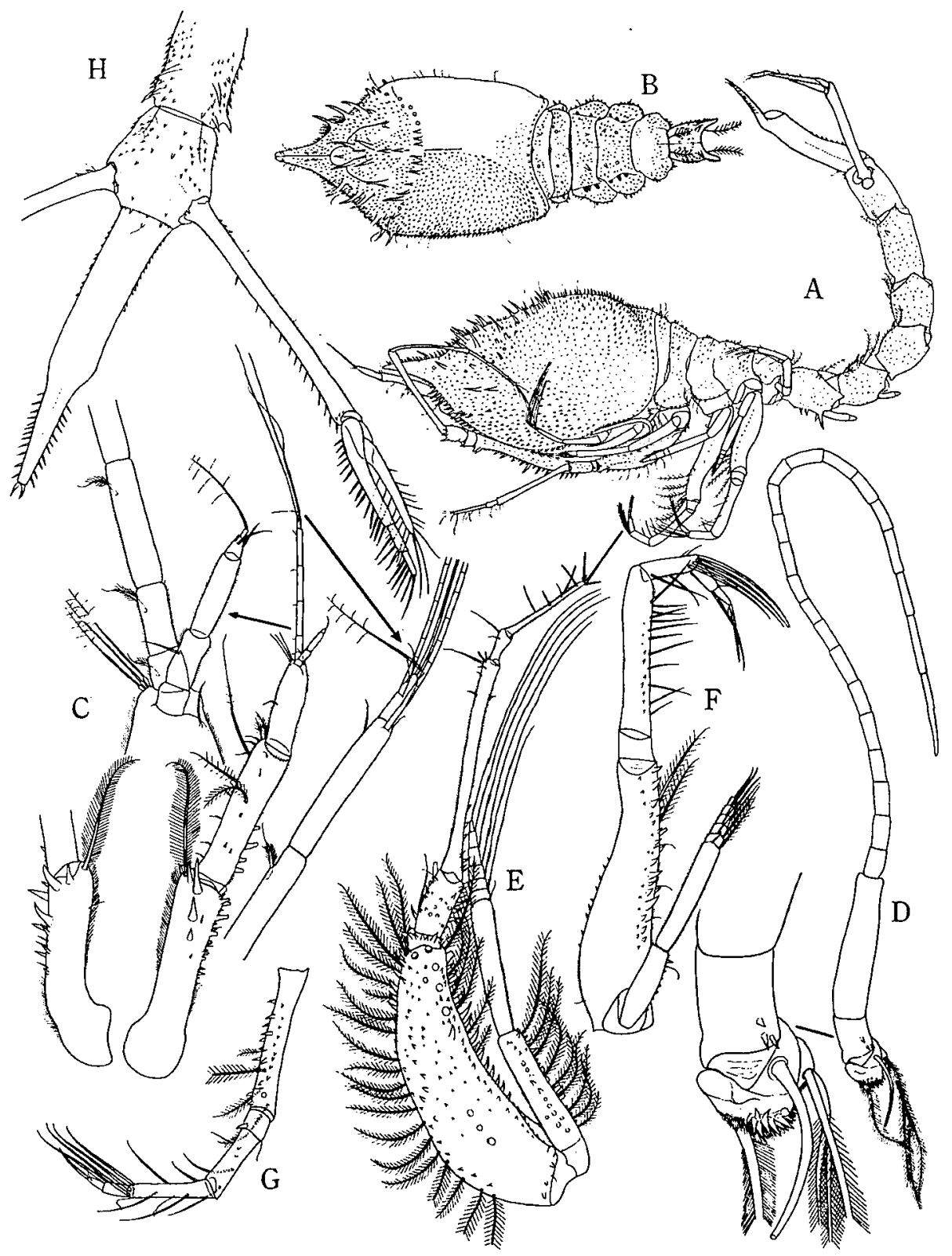

Fig. 32. Diastylis ulinomii sp. nov., paratypc young male $(12.5 \mathrm{~mm})$. A: lateral view. B: anterior portion of body, dorsal (spinules of left posterior region of carapace omitted). C: antennule. D: antenna. E-G: second, third and fifth peraeopods. $\mathrm{H}$ : uropod with telson and last two abdominal segments. 
and longer than in the female; the propodus is one and one-fifth times the length of the carpus. The dadtylus is a little longer than a half of the propodus.

The second peraeopod is a little longer than a half of the first. The basis is one and one-fourth times the total length of the remaining distal segments. The carpus is a little shorter than three times the propodus.

The third peraeopod is a little shorter than four-fifths of the second and a little longer than the fourth. The basis of the third and fourth peraeopods is roubust and bears the exopod. In the third peraeopod the basis is a little shorter than the remaining distal segments together, and that of the fourth is much shorter than the total length of the distal segments. The fifth peraeopod is one-third as long as the fourth and its basis is two-thirds as long as the remaining distal segments together.

The telson is a little shorter than three times the last abdominal segment; the preanal portion is about two-thirds as long as the telson itself and bears one spinule and a seta on the dorsal surface of the proximal portion, a longitudinal row of small teeth on each side and a similar row of eight teeth in the middle of the ventral surface; the post-anal portion bears 11 lateral spines on the right and 12 on the left border and a pair of apical spines.

The peduncle of the uropod is a little shorter than the telson and furnished with 13 (left) or 12 (right) spines on the inner border, two or three spinules on the proximal portion of the outer border and three spinules on the distal portion of the dorsal surface. The endopod is nearly one-third as long as the peduncle and three-segmented; the first segment is twice as long as the distal two subequal segments together and bears on the inner border 14 spines which are increasing in length distally; the distal two segments with similar spines on the inner border: $3,4+1$ (apical) spines respectively. The exopod is four-fifths as long as the endopod and bears eight setae on each lateral border and two apical setae.

Material: 2 o (1 9 holotype), 3 o young (paratype); KT 64-17, Plankton Rec. -2 ; Sagami Bay $\left(35^{\circ} 6^{\prime} 30^{\prime \prime} \mathrm{N}, 139^{\circ} 17^{\prime} \mathrm{E}\right)$; $2000 \mathrm{~m}$ wire out, maximum depth about $1000 \mathrm{~m}$; collected by oblique haul of ORI-net (Ocean Research Institute-net for macorplankton); 25 October, 1964 (Time: 16.34-17.45); coll. Dr. M. ÓMorI.

Remarks: The new species bears some superficial resemblance to $D$. horrida SARs from Kerguelen I. (SARS, 1887) and Makrokylindrus josephinae (SARs) from the norhtern Atlantic (SARS, 1871; FAGE, 1951), but it differs from the two old species in that its carapace is almost encircled anteriorly by slender strong spines and its telson and uropod are different in structure and provided with a different spination.

In the female holotype, the segmentation between the third and fourth free thoracic segments is obscure and discernible only as a suture line on the dorsal side.

\section{Diastylis matsuei sp. nov.}

(Figs. 33-35)

Diastylis sp. (B), Gamô 1967b, p. 23, pl. 2, fig. 15. 
Holotype: An adult female (12.1 $\mathrm{mm}$ in length, exclusive of telson) with well developed marsupium, in which 63 eggs (about $0.4 \mathrm{~mm}$ in diameter) are carried. The carapace is covered with spinules on a finely reticulated surface (see Fig. 34, A). In dorsal aspect the carapace is robust; the anterior portion is abruptly narrowed anteriorly in the region of the pseudorostum and with a large round knob-like protuberance with spinules on each side; the posterior portion is very gently narrowed posteriorly and with a small swell near the hind margin on each side. The narrow dorso-median groove is flanked on both sides by the inflated branchial regions. On each side of the carapace shallow depressions are seen with difficulties beneath the spinules and their arrangement seems to be rather regular. On the frontal lobe there are two humps divided by a shallow transverse depression and each surrounded by spinules; the anterior hump with a semi-circular depresison encircled by spinules and the posterior hump with a longitudinal oval median depression. On each side of the anterior portion of the carapace there is a curved groove extending from the hind part of the frontal lobe to the base of the pseudorosturm. The carapace length is a little less than the body length and about one and one-third times the width which is greatest across the posterior one-third and about one and half times the depth. The ocular lobe is large, semi-circular in shape, with seven spines but without discernible ocelli. The antennal notch is shallowly sinuated and furnished with conspicuously serrated teeth. The antero-lateral and lower margin of the carapace is serrate. The pseudorostrum horizontally projects out in front of the carapace, though rather short, about one-sixth as long as the carapace.

The total length of the free thoracic segments is a little more than one-fifth of the animal. The third segment is a little longer than the second which is about as long as the first, when they are measured along the median line. The second segment is slightly broader than the first and a little narrower than the carapace. The second to fifth segments are successively narrowed posteriorly. The second, third and fourth segments seem to be partly fused, namely dorsally and laterally. In dorsal aspect the integument of the segments is furnished with sparse spinules; on the third and fourth segments there are a pair of prominent submedian spines; on the fifth segment the submedian spines are very strong and directed obliquely outwards and backwards. The fourth segment is furnished with a pair of submedian dorsal swellings, each with four spines arranged in a row. The anterior margin of the first, second and fifth segments is fringed with fine teeth. As seen from the side, the segments decrease the the height or depth posteriorly. The side plates are spinulose and rather prominent.

The abdomen is slightly longer than three-sevenths of the total body. The first three segments are approximately of the same size. The fourth segment is slightly longer than the third. The fifth is the longest and about one and one-fifth as long as the fourth or the sixth segment. Each segment is rather spinulose dorsally and laterally; the spinules are arranged in a row along the hind margin; the post-lateral articular process with one spine. On the dorso-submedian portion of the first two 


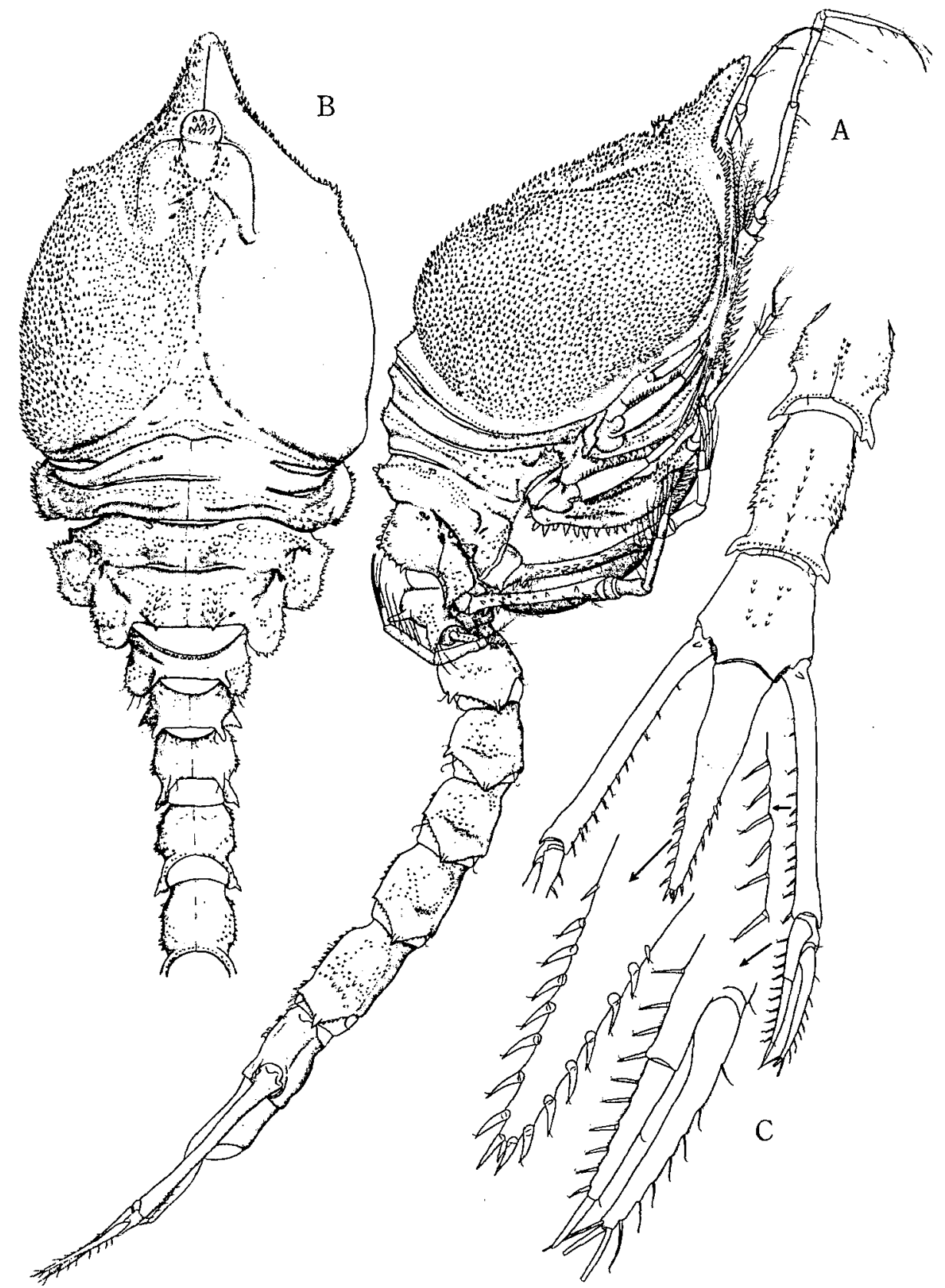

Fig. 33. Diastylis mastuei sp. nov., holotype ovigerous female $(12.1 \mathrm{~mm})$. A: lateral view. B: anterior portion of body, dorsal (spinules of left side of carapace omitted). C: uropods with telson and last three abdominal segments. 


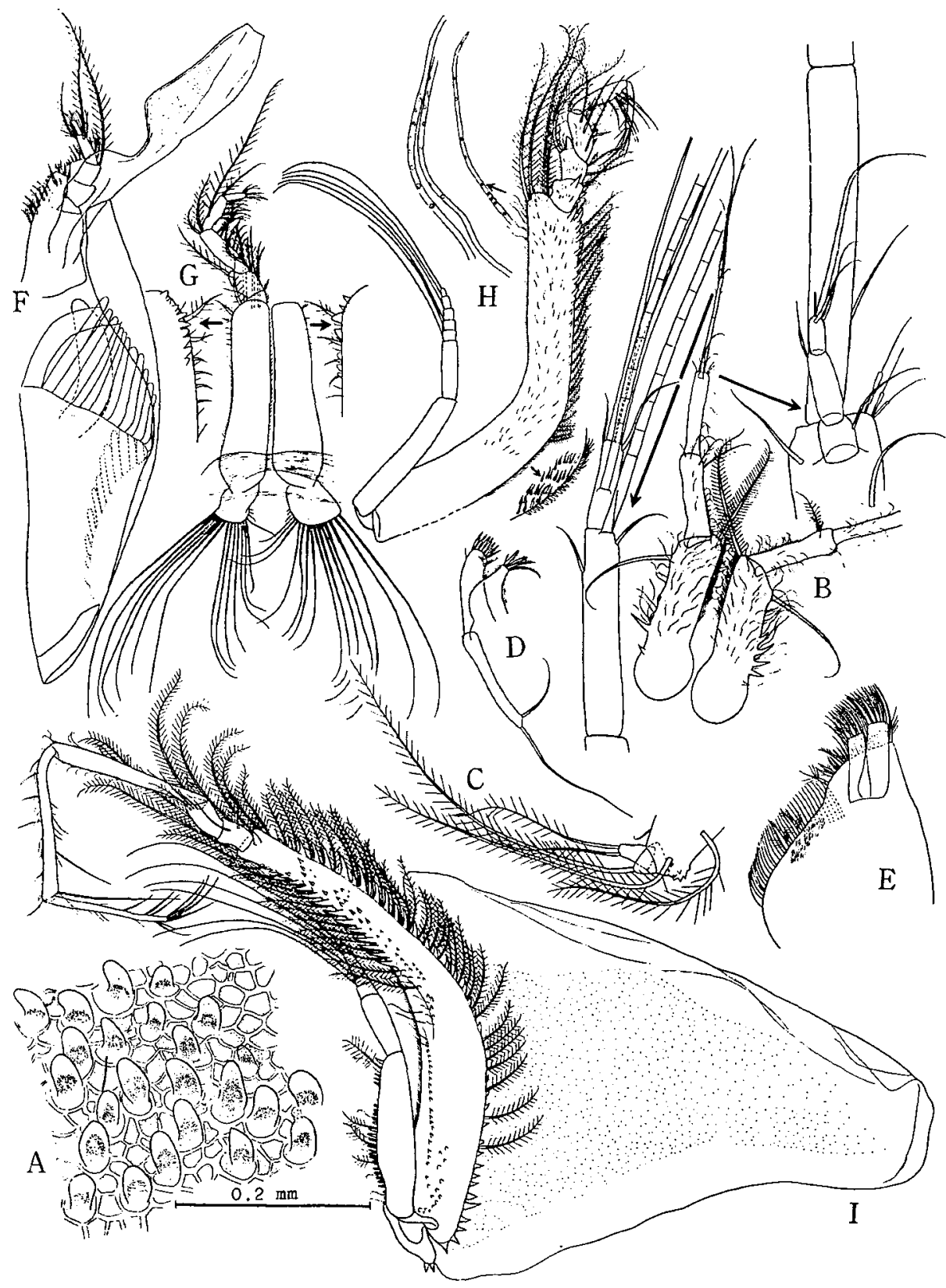

Fig. 34. Diastylis malsuei sp. nov., holotype ovigerous femalc. A: sculpture of carapace surfacc. B: antennule. C: antenna. D-E: maxillula and maxilla. F-H: first to third maxillipeds. I : first peraeopod. 
segments there are a pair of strong spines directed outwards and backwards.

The first segment of the antennular peduncle is about as long as the distal two segments combined, hairy, and bears four or five spines arranged in a row on the outer border. The third segment is slightly shorter than the second. The main flagellum is two-segmented; the first segment is long and the second is about half as long as the first and bears a segment-like protuberance and four long aesthetascs. The accessory flagellum is three-segmented and about one-fourth as long as the main lash; the first and third segments are short, whereas the second is long.

The antenna is shown in Fig. 34, C.

The mandible bears 15 plumose spines on the right and 14 similar spines and a lacinia mobilis on the left side.

The maxillula and maxilla are shown in Fig. 34, D and E.

The first maxilliped bears about 25 lobules and an accessory one on the branchial apparatus.

The second maxilliped has 14 filaments and three rudimentary ones on the coxal segment (Fig. 34, G).

The basis of the third maxilliped is a little shorter than twice the remaining distal segments together; the ventral surface is covered with fine setules and the inner border with strong spines and plumose hairs distally. The ischium is provided with one stout spine on the distal portion and serrations on the inner border. The merus bears a stout tooth on the outer distal portion. The carpus is furnished with three teeth on the inner border.

The basis of the first peraeopod is nearly as long as the remaining distal segments together, a little spinose on the ventral surface and provided with strong spines and plumose hairs on the inner border, also strong spines and plumose hairs on the distal half of the outer border, and one strong spine on the ventral surface. The ischium and merus are without any spines. The carpus and propodus are subequal to each other in length and the dactylus is a little shorter than the propodus. The peduncular segment of the exopod bears slender spines in a row along the outer border.

The second peraeopod is a little shorter than one-half of the first. The basis is six-sevenths as long as the remaining distal segments together; the ventral surface is a little spinose, the outer border with strong spines and the inner border with storng spines and plumose hairs. The ischium is provided with a large spine at its distal inner angle. The merus is about one-third as long as the carpus, a little spinose on its inner border and bears a pair of strong spines on its distal end. The carpus is slender, one and two-thirds times the distal two segments combined. The dactylus is a little longer than the carpus and provided with three long setae at the apex, two of which are much longer than the dactylus.

The third and fourth peraeopods have no exopod. The third peraeopod is a little longer than the fourth and four-fifths as long as the second; the basis of the third is much longer than the remaining distal segments together, while that of the fourth 
is slightly shorter than the total length of the distal segments. The fifth peraeopod is slightly longer than three-fourths of the fourth and the basis is two-thirds of the total length of the distal segments.

The telson is about twice as long as the last abdominal segment; the pre-anal portion is about one-half of the telson length; the post-anal portion bears eight (right) or seven (left) spines on the lateral borders and three apical spines, of which the middle one is rather small.

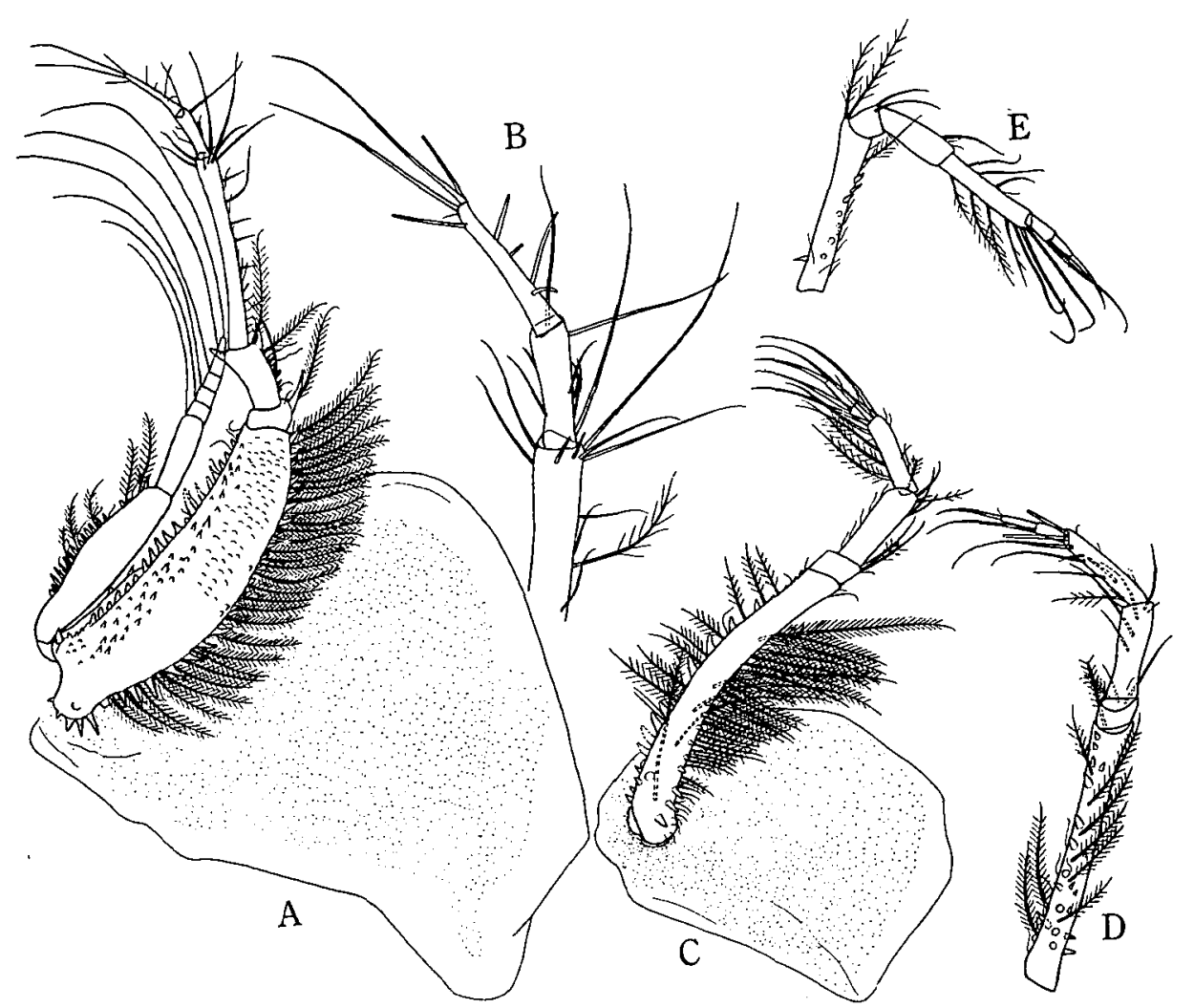

Fig. 35. Diastylis matsuei sp. nov., holotype ovigerous female. A-B: second peraeopod and its distal portion. C-E: third to fifth peraeopods.

The peduncle of the uropod is a little longer than the telson and provided with one spine at the base and 12 spines on the inner border. The endopod is one-half as long as the peduncle and two-segmented; the first segment is slightly shorter than the distal one and bears four spines on the inner border; the distal segment bears six spines on the inner border and one spine at the apex. The exopod is slightly longer than the endopod and bears seven setae on the outer border and three spines at the apex.

Material: 2 ovigerous ( 1 holotype) and 1 q subadult; KT 64-17, Plankton 
Rec. -2; Sagami Bay $\left(35^{\circ} 6^{\prime} 30^{\prime \prime} \mathrm{N}, 139^{\circ} 17^{\prime} \mathrm{E}\right)$; $2000 \mathrm{~m}$ wire out, maximum depth about $1000 \mathrm{~m}$; collected by a oblique tow of ORI-net (Ocean Research Institute-net for macroplankton); 25 October, 1964 (Time: 16.34-17.45), coll. Dr. M. ÔMorI.

Remarks: The new species somewhat resembles the following four species in possessing an antero-lateral blunt tooth on each side of the carapace: $D$. bidentata Calman (Calman, 1912; Lomakina, 1958b), D. planifrons Calman and D. argentinata Calman (Calman, 1912), but it differs from them in that the carapace is closely covered with uniform spinules. In some respects the species approaches $D$. loricata Lomakina from Zaliv Petra Velikogo (Lomakina, 1958b), from which it differs, however, in that the telson bears three apical spines and the dorsum of the second to fourth free thoracic segments is devoid of a pair of strong spines.

In the present species the second, third and fourth free thoracic segments seem to be fused dorsally and laterally.

\section{Diastylis sp.}

Diastylis sp., ZIMMER 1943, p. 135.

An adult male (length, $12 \mathrm{~mm}$ ) collected from off southern Hokkaido $\left(42^{\circ} 02^{\prime} 40^{\prime \prime}\right.$ $\left.\mathrm{N}, 142^{\circ} 33^{\prime} 20^{\prime \prime} \mathrm{E}\right)$. The surface of the carapace is smooth and without any folds nor teeth. The telson is nearly as long as the last two abdominal segments together; its pre-anal portion is cylindric; the post-anal portion is about two-fifths of the telson length and bears eight pairs of lateral spines.

\section{Genus Makrokylindrus SteBbing, 1912.}

Twenty-eight species have been described. They inhabit the deep sea bottom more than $1000 \mathrm{~m}$ or so; the maximum depth $7160 \mathrm{~m}$, the Sunda Trench, collected by "Galathea II" (BRUUn, 1956; BÁcEscu, 1962), rarely obtained from the depth less than $200 \mathrm{~m}$. BÁcEscu (1961 and 1962) divided the genus into three subgenera, Makrokylindrus, Coalescuma and Vemakylindrus, and prepared a key to all the species hitherto be known.

\section{Makrokylindrus (?) jedsi HARADA}

Makrokylindrus jedsi HARADA 1962, p. 173, fig. 3, 4.

Female with marsupium (about $15 \mathrm{~mm}$ ): The carapace is densely covered with minute spinules and without carinae; the anterior part of the ventral margin is denticulated below the distinct antennal notch.

The free thoracic segments, excepting the first, are also armed with spinules. The post-lateral margin of the abdominal segments is produced posteriorly to form 
a point tip. In the posterior part of each segment there are 3-4 pairs of dorsal spinules.

The telson is nearly more than twice as long as the last abdominal segment; the cylindrical pre-anal portion is quite smooth, and much longer than the last abdominal segment; the post-anal portion is furnished with acute lateral spines (about four pairs or more).

The basis of the third maxilliped is flattened and more than twice as long as the distal segments together; its external angle is protruded, scarcely reaching the tip of the ischium, and bears eight long setae; the inner border bears a series of sharp sipnes. The ischium, merus and propodus are serrated along the inner border. The propodus is longer than the dactylus.

The first two pairs of pleopods have each the well developed exopod, but the third and fourth pairs are devoid of it. The basis of the first peraeopod bears a series of acute spines intermingled with setae on the inner border and two similar spines on the outer border.

The basis of the second peraeopod is a little longer than the ischium, merus and carpus combined; the carpus is almost three times the ischium and merus together.

Remarks: According HARADA's original description of $M$. jedsi, the single adult fernale specimen which was available was highly injured, especially in the carapace, and lacked antennulae, antennae, the distal part of the first and second peraeopods, the main part of the uropods and the tip of the post-anal portion of the telson, so that the exact detailed observations were imposible.

In some respects the species resembles $M$. vitiasi Lomakina (Lomakina 1958b). For the present, any definite statement of the status of this species would be reserved, until further materials become available.

Distribution: Off Onagawa $\left(37^{\circ} 35^{\prime} \mathrm{N}, 143^{\circ} 25^{\prime} \mathrm{E}\right)$, depth $2350 \mathrm{~m}$.

Genus Diastylopsis S. I. SмIтH, 1880.

\section{Diastylopsis dawsoni forma calmani DERZHAVIN}

(Colour Plate Fig. 9)

Diastylopsis Calmani Derzhavin 1926, p. 176, pl. 4.

D. dawsoni forma calmani Lomakina 1955a, p. 152; 1958b, p. 169, fig. 99: Gamô 1965b, p. 215, fig. $12 ; 1965$ c, p. 536, fig. 705.

Body length, 7.5-14.5 mm. This species was first described as Diastylopsis Calmani by Derzhavin (1926). Lomakina (1958a) suggested that D. Calmani was only a form of $D$. dawesoni Smith (1880) which ranges from Alaska to Californian waters. D. dawsoni forma calmani DERZHAvin is closely allied to dawsoni froma typica Smith (Lomakina, 1955a; 1958b), but the former is distinguished from the latter by possessing the round antero-lateral angle with serrations in the female and the telson 
with the longer distal sipne (in forma calmani, the distal spines is nearly half as long as the telson, but in forma typica it is only one-third of the telson length).

In general, the body is whitish when ailve and the dark brownish contents of the digestive tube are visible through the translucent integument. The cephalic portion is sometimes slightly coloured grayish yellow. The ocular lobe is reddish white, the ocelli are scarecely visible.

Distribution: Akkeshi Bay, night surface plankton and sandy mud bottom about 1-15 m deep; the Bering Sea, the Sea of Okhotsk and northern part of the Sea of Japan.

\section{Genus Paradiastylis Calman, 1904. Paradiastylis longipes CALMAN}

Paradiasiylis longipes Calman 1905, p. 21, fig. 4a-i; 1911, p. 376; Zimmer 1908, p. 181; SteBbinG 1913, p. 122, figs. 75-76; MaruKawa 1921, p. 857, fig. 2460; Hale 1945, p. 177; Kurian 1951, p. 106 .

Female: Body length, 3-3.4 mm. The lateral surface of the carapace has three oblique ridges, no strong dorsal teeth, only a pair of denticules on the ocular lobe and a few of them in front of the anterior oblique ridges; the paired longitudinal crests on the hind part of the dorsal surface are faintly serrated and rather prominent, and the space between them is deeply hollowed. The third and fourth free thoracic segments are indistinctly separated. The abdomen is slender and its lateral serrations are rather large and numerous.

The third peduncular segment of the antennule is rather long and slender. The basis of the third maxilliped is rather narrow and without the exopod. The first peraeopod is long, the following peraeopods are also rather slender. The peduncle of the uropod is three times as long as the last abdominal segment.

Male: Body length, 3.5-3.7 mm. The sculpture on the carapace is less strongly marked than in the female; the broad ocular lobe has three large but incompletely defined corneal lenses. The abdominal segments are quite smooth. The pre-anal portion of the telson is cylindrical and relatively longer than in the female, and bears a pair of spinules adjacent to the apical pair. The flagellum of the antennule is foursegmented. The basis of the third maxilliped is much broader than in the female, in accord with the well-developed exopod. The basis of the first four pairs of peraepopds is greatly expanded and distally protruded out. The endopod of the uropod is furnished with $6,3,3$ spines on the three segments respectively; the third segment is longer than the second.

Distribution: Tôkyô Bay, Sagami Bay, Wakayama and Kagoshima (Marukawa, 1921); the Gulf of Siam, 9-18m; the Sulu Archipelago, surface to $23 \mathrm{~m}$; India (Trivandrum), 13 fathoms; New South Wales, 8 feet deep. 


\section{Genus Dimorphostylis Zimmer, 1921.}

Very near to Paradiastylis and Leptostylis. The post-anal portion of the telson extremely reduced. In adult male, the basis of first to fourth peraeopods greatly expanded and with the well-developed exopod, and the flagellum of the second antenna reaching at least the end of the pleon. The third maxilliped with the exopod in both sexes. In female, the third and fourth peraeopods are quite devoid of exopod.

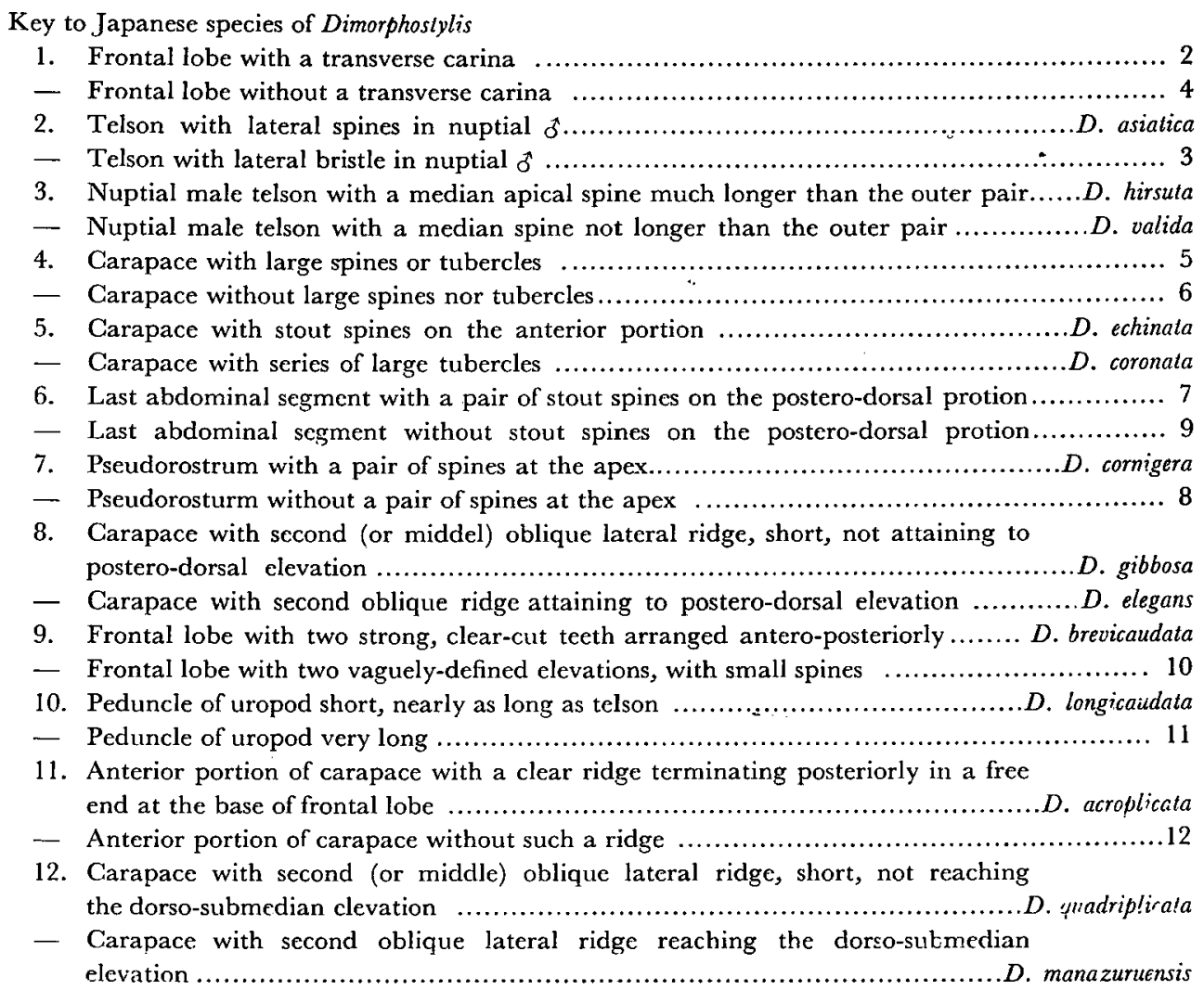

\section{Dimorphostylis asiatica ZIMMER}

Dimorphostylis asiatica Zimmer 1921, p. 144, figs. 45-47; FAgE 1945, p. 220, fig. 43; Lomakina 1955a, p. 153 ; 1958a, p. 211 ; 1958b, p. 169, fig. 100; GAMO 1960a, p. 387; 1960c, p. 118, pl. 59, fig. 9 ( $\delta$ coloured); 1962b, p. 200; 1963a, p. 59; 1965b, p. $217 ; 1965$ c, p. 536, fig. 706; HARADA 1960, p. 203, fig. 2.

Body length, 2.2-4 mm. This species is one of the commonest cumaceans found on the Japanese coasts. The carapace of male is rather depressed dorso-ventrally, in the female somewhat raised and furnished with four oblique lateral ridges; the first ridge originates at the lateral side of the base of the pseudorosturm and traverses the 
dorsal surface of the frontal lobe, the second, third and fourth ridges run obliquely almost parallel with one another keeping roughly a regular interval between them and all of them are interrupted on the dorso-median by a shallow longitudinal depression. The post-anal portion of the male telson is narrow and projected backward being furnished with 2 or 3 pairs of lateral spines and three apical spines; the female telson is rather short and provided with two minute apical spines and three pairs of lateral hairs or bristles.

Distribution: Hokkaidô, Sado I., Shinzi Lake (Tottori Prefecture), Tôkyô Bay, Sagami Bay, Izu Peninsula, Kii Peninsula, Kôchi, Tamano (Okayama Prefecture), Nagasaki, Amami-Ôshima I.; Zaliv Petra Velikogo, Shikotan I. (Southern Kuril), Formosa, Viet-Nam; 0-100 $\mathrm{m}$ deep, sandy bottom and night surface plankton.

\section{Dimorphostylis valida HARADA}

Dimorphoslylis valida Harada 1960, p. 205, fig. 3.

Male (4.8 $\mathrm{mm}$ long): This species very closely resembles $D$. asiatica, but the former is distinguishable from the latter by the following characters: 1) the first and second oblique ridges on the carapace are converging anteriorly at the side of the pseudorosturm, 2) the basis, ischium and merus have a hook on the distal margin respectively, 3) the telson in nuptial male has three acute apical spines and three pairs of lateral bristles.

Female (4.1 mm long): The carapace is rather short and rounded. The ridges on the carapace closely resemble those of the male. The telson bears two minute apical spines and three pairs of lateral bristles, besides a pair of spines.

Distribution: Sagami Bay (Shimoda), Gunchuko (Ehime Prefecture), Tamano, Kochi.

\section{Dimorphostylis acroplicata HARADA}

Dimorphostylis acroplicata HARAdA 1960, p. 210, fig. 5.

Body length, $4.6\left(\delta^{\circ}\right)$ and $4.5 \mathrm{~mm}$ (q subadult). This species is closely related to $D$. asiatica and $D$. valida, from which the former is distinguishable by that the free end of the first oblique ridge on the carapace terminates at the basal part of the frontal lobe and thus the ridge does not encircle the dorsal surface of the carapace. The ridges on the carapace of the subadult female are quite similar to those in the male.

Distribution: Sagami Bay (Shimoda), Gunchuko (Ehime Prefecture).

\section{Dimorphostylis hirsuta GAMô}

Dimorphosiylis hirsuta Gamo 1960a, p. 107, 111 , fig. 8.

D. exigua, Harada 1960, p. 207, fig. 4 . 
Body length, $3(\hat{\delta}), 3-6 \mathrm{~mm}$ (ㅇ). This species closely resembles $D$. asiatica, $D$. valida and acroplicata, but the former is distinguished from the latter three only by the male character - the post-anal portion of the telson is gradually tapered posteriorly and provided with two pairs of lateral bristles and three apical spines, of which the middle one is very long and attaining beyond three times the length of the outer pair. In the female the carapace is somewhat rounded and furnished with very similar ridges respectively fringed with a row of minute spinules and hairs; the telson has the shorter post-anal portion with two pairs of lateral bristles and two apical spines.

Distribution: Sagami Bay (about $30 \mathrm{~m}$ deep).

\section{Dimorphostylis manazuruensis GAMô}

Dimorphostylis manazuruensis GaMô 1960a, p. 101, 108, figs. 1-2.

D. triplicata HaRAda 1960, p. 212, fig. 6.

Body length, 4.7-5.2(), $5 \mathrm{~mm}\left(\delta^{*}\right)$. The carapace is provided with three oblique lateral ridges which are fringed with fine serrations; they are almost parallel with one another keeping subequal intervals between them, in addition another faintly marked ridge is seen near the posterior margin. On the dorsal surface the ridges merge into the submedian dorsal crest which is raised on each side of the median longitudinal depression. The post-anal portion of male is narrowly projected backward and provided with three apical spines and four pairs of lateral bristles. In the female the carapace sculpture is very like the male, but spines on the frontal lobe; the telson is rather short and bears two minute apical spines and four pairs of lateral bristles.

Distribution: Sagami Bay, Tamano; sandy mud bottom, about $20 \mathrm{~m}$ deep.

\section{Dimorphostylis quadriplicata GAMÔ}

Dimorphostylis quadriplicata Gamô 1960a, p. 106. 110, fig. 7.

D. tagoensis HARAda 1960, p. 241, fig. 7.

Body length, 5.6-6.3 (ㅇ), 5.4-6.1 mm ( $\left.\delta^{3}\right)$. The carapace is provided with four crenated lateral oblique ridges; the second is very short and the fourth is very faintly marked; the first ridge originates on the lateral side at the base of the pseudorostrum and almost annularly encircles the carapace just behind the frontal lobe; and the third arises in the anterior part of the lower margin of the carapace and merges into the submedian dorsal crest which is raised on each side of the dorso-median longitudinal depression. The female telson is rather short and provided with two minute apical spines and three pairs of lateral bristles. The telson of subadult male is similar to that of female.

Distribution: Sagami Bay; sandy bottom, 30-50 m deep. 


\section{Dimorphostylis longicaudata GAMÔ}

Dimorphostylis longicaudata GAMó 1962b, p. 200, figs. 35, 36.

Young female (2.6 mm long): The carapace has three oblique folds on each side. On the frontal lobe there are small scattered spines and two indistinct elevations with spinules. The antennal notch is shallowly concave. The round antero-lateral angle and the lower margin of the carapace are faintly serrated. The pseudorostrum is subacutely projected forward. The ocular lobe is large and beset with three ocelli. The basis of the third maxilliped with rather small exopod, one and one-sixth times as long as the remaining distal segments together. The basis, ischium and merus are provided each with a tooth at distal inner angle. The telson is relatively large, nearly as long as the last abdominal segment, and one-half as wide as its length; it bears two spinules and two setules at the apex and two pairs of small lateral setae.

Distribution: Kii Peninsula (Shirahama), night surface plankton.

\section{Dimorphostylis brevicaudata (ZIMMER)}

(Fig. 36)

Leptosiylis brevicaudata ZiMmRT 1903, p. 685, figs. W-Y.

Paradiastylis (?) brevicaudata, CALman 1904, p. 175; ZMMmer 1908, p. 181.

P. brevicaudatus, StebBing 1913, p. 121.

Male (about $9 \mathrm{~mm}$ long): The pseudorostrum is acute and horizontally projected. The antero-lateral corners are subacute, forming a well marked sinus. The ocular lobe is small and provided with three ocelli and a pair of denticles. The carapace is heavily sculptured and frunished with two strong teeth arranged antero-posteriorly on the frontal lobe. The upper margin of the first strong tooth on the frontal lobe is faintly denticulated. There is a deep median depression on the posterior half of the carapace which is flanked on each side by a pair of keels that issue respectively four lateral keels curving forward; the hind margin of the carapace is dorsally raised.

The fourth free thoracic segment is the longest and provided with a dorsal pair of quadrate impressions; the fifth segment is furnished with a post-dorsal upturned conical process. The fifth abdominal segment is the longest. The telson is slightly shorter than the sixth segment; and its narrow distal portion is much shorter than the broad proximal and provided with a pair of lateral spines and a small apical pair with an accessory adjacent pair of setules.

The antennule is rather long and slender. The first peraeopod is long. The third and fourth pairs bear the exopod.

The peduncle of the uropod is longer than twice the telson which is longer than the endopod; the first segment of the endopod is about twice as long as the second and third segments combined, the second nearly twice the third, the spines of the medial margin respectively $5,2,1$; the exopod is a little shorter than the endopod. 
In juvenile male (about $6 \mathrm{~mm}$ long) the basis of the third and fourth peraeopod is robust and bears the exopod.

Ovigerous female (6.5 $\mathrm{mm}$ long): In general the body is very like the male. The third and fourth peraeopods are quite devoid of exopod. The third maxilliped is provided with the well developed exopod which is a little reduced in size.

Remarks: Examining the materials obtained from Sagami Bay and Amakusa, this species is now referred to the genus Dimorphostylis for the following characters:
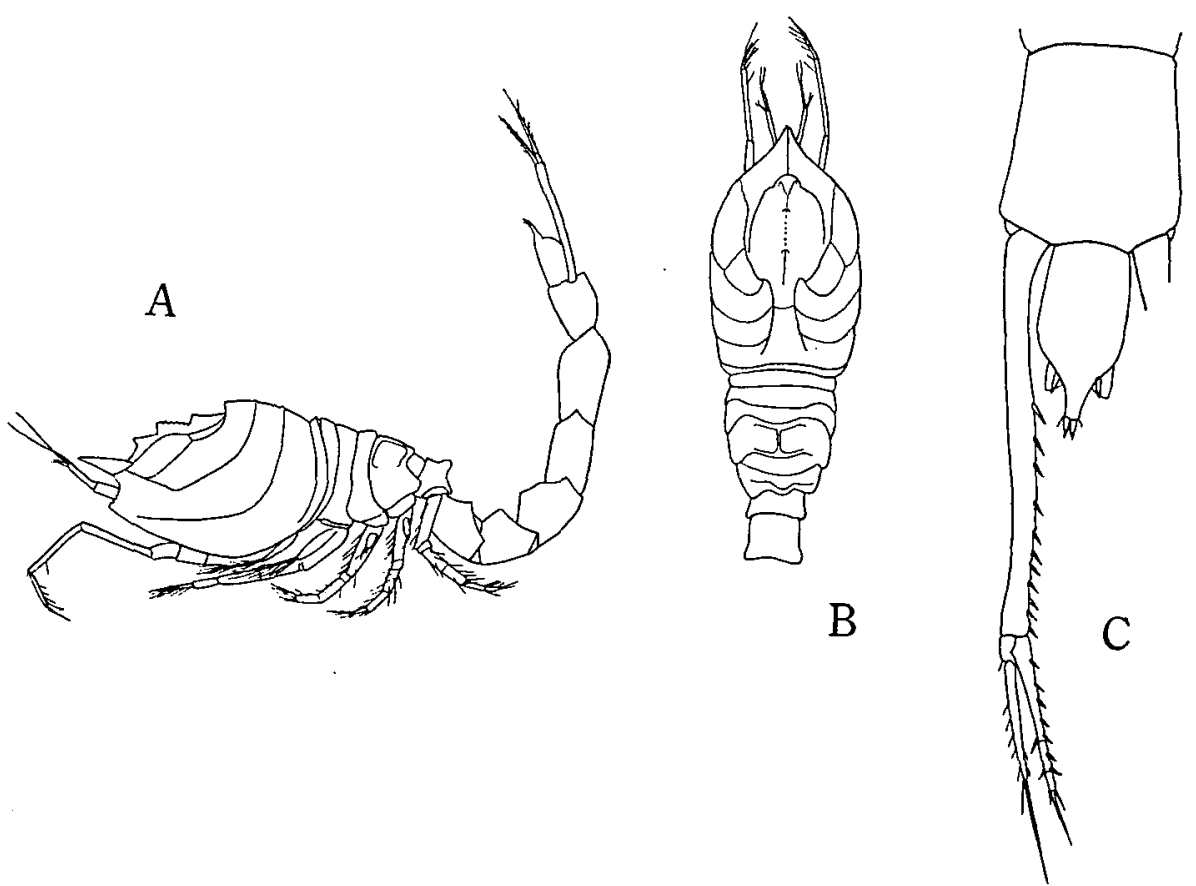

Fig. 36. Dimorphostylis brevicaudata (ZrMmer). Young (?) male (ca. $9 \mathrm{~mm}$ ). A: lateral view. B: anterior portion of body, dorsal. C: uropod with telson and last abdominal segment. (after ZiMMER, 1903).

1) the third maxilliped of female is provided with the exopod and 2) the basis of the third and fourth peraeopods in the male is robust and provided with the exopod, while in the female the exopod is missing on the corresponding appendages.

Distribution: Sagami Bay, Amakusa. A considerable number of the specimens were collected from the sandy bottom at the low tide level, in the shallow depth, and by night surface tow.

\section{Dimorphostylis echinata GAMÔ}

Dimorphostylis echinata GAMô 1962b, p. 203, figs. 37-38; 1963a, p. 59. 
Young female (2.4 $\mathrm{mm}$ long): On the antero-dorsal surface of the carapace there are strong spines almost encircling the frontal lobe. Three tumidities, each with three or four spines, are on the frontal lobe. Three oblique folds are present on each side of the carapace. The ocular lobe is rather large and provided with a pair of spines. The pseudorosturm is almost horizontally projected forward. The antennal notch is shallowly concave. The antero-lateral corner and the lower margin of the carapace are conspicuously serrated. The telson is a little shorter than the last abdominal segment; the lateral side of the proximal portion is somewhat swollen and with spinules; the post-anal portion has three pairs of lateral spines and a pair of spinules and setules at the apex.

Young male $(2.5 \mathrm{~mm}$ long): Very like the young female. The telson is about as long as the last abdominal segment.

Distribulion: Kii Peninsula (Shirahama), Amami-Ôshima I.; night surface haul and sandy bottom about $1 \mathrm{~m}$ deep.

\section{Dimorphostylis coronata GAMô}

Dimorphostylis coronata GAMO 1960a, p. 104, 110, figs. 5, 6; 1960c, p. 118. fig. 10 ( 9 coloured).

D. denticulata HARAda 1960, p. 216, fig. 8.

Female (4.7-6 $\mathrm{mm}$ long): The body integument is covered with fine spinules and beset with scattered small tubercles. The carapace bears large protuberances arranged in three oblique rows on each side. The last abdominal segment has a pair of small spines on the posterior margin. The peduncle of the uropod is about $2-1 / 2$ $\sim 3$ times as long as the telson and furnished with ten spines on the inner border. The endopod is slightly longer than the exopod; the first segment of the endopod is one and one-third times as long as the two distal subequal segments combined. The telson is nearly as long as the last abdominal segment and provided with two minute apical spines and a few lateral hairs.

Male (5.2 $\mathrm{mm}$ long): In general the male is very like the female. The peduncle of the uropod is about two and one-third times the length of the last abdominal segment and about three times as long as the telson.

Distribution: Sagami Bay, Amakusa; sandy bottom, about $20 \mathrm{~m}$.

\section{Dimorphostylis elegans GaMô}

Dimorphostylis elegans Gamô 1960a, p. 102, 109, figs. 3, 4.

D. latifrons Harada 1960, p. 200, figs. 10, 11 .

Female (5.1-5.4 mm long) and male (5.1 mm long): This species resembles the following two species. The body integument is beset densely with minute dark spots on the finely granulated surface. The carapace bears three strong oblique lateral ridges on each side. In another specimen from Sagami Bay the postero-dorsal 
portion of the posterior-most lateral ridge on the carapace is rather inconspicuously marked.

Distribution: Sagami Bay. Sandy bottom with shell fragments, about $40-50 \mathrm{~m}$.

\section{Dimorphostylis gibbosa HARADA}

Dimorphostylis gibbosa HARADA 1960, p. 218, fig. 9.

Body length, subadult $q-5 \mathrm{~mm}$, sudadult $\hat{o}-5.8 \mathrm{~mm}$. This species is closely allied to $D$. elegans, from which it is distinguishable only by that the posterior end of the second (or middle) oblique lateral ridge does not extend to the postero-dorsal elevation of the carapace.

Distribution: Sagami Bay (Izu Peninsula).

\section{Dimorphostylis cornigera HARADA}

Dimorphostylis cornigera HARADA 1960, p. 222, fig. 12.

Body length, $5 \mathrm{~mm}$ in either sex in adult specimen. This species resembles $D$. elegans and D. gibbosa; the former is easily distinguished from the latter two by the following characters: 1) the first lateral ridge on the carapace is produced outward at about the anterior one-third of the carapace and then runs nearly straight backward to meet the third ridge; from this meeting point another ridge runs out inward to merge into the dorso-median carina which is well marked on the frontal lobe, 2) the second oblique lateral ridge is rather short and isolated from the first and third ridges, 3) the pseudorostrum is laterally expanded at the base and provided with a pair of strong spines at the apex, and 4) there is one strong spine on the anteromedian portion of the frontal lobe.

Distribution: Sagami Bay (Izu Peninsula).

\section{Genus Gynodiastylis Calma N, 1911.}

Key to Japanese species of Gynodiastylis

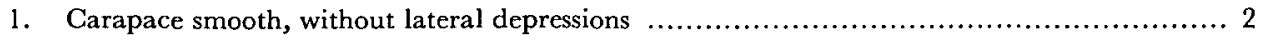

- Carapace sculptured, with longitudinal ridges and lateral depressions. Inner ramus of uropod with two segments

2. Inner ramus of uropod with three segments. First three pairs of peraeopods with the exopod in the male

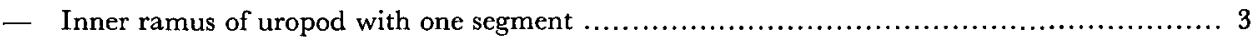

3. Carpus of the first peraeopod with membranous lamella on its inner border. Telson rounded ( $\delta$ unknown) G. rotundicaudata

- Carpus of the first peraeopod without membranous lamella on its inner border. Telson subcordate ( $\sigma$ with the exopod on the third and fourth peraeopods) G. nitida

4. Carapace with numerous longitudinal ridges ( $\delta$ with the exopod on the third and fourth peraeopods) G. costata 
- Carapace with paired clear ridges ( $\sigma^{*}$ with the exopod on the third and fourth peraeopods)

5. Carapace with paired ridges extending from its hind margin anteriorly to the fronto-lateral ridges

- Carapace with paired ridges extending from its hind margin anteriorly, but ending close to the fronto-lateral fissure

6. Pseudorostrum with longitudinal carinae. G. angicephala

- Pseudorostrum without longitudinal carinae G. bicristata

\section{Gynodiastylis platycarpus GAMô}

Gynodiastylis platycarpus GAMO 1961, p. 105, figs. 1, 2; HARADA 1962, p. 297, figs. 2, 3.

Ovigerous female (3.7-3.9 $\mathrm{mm}$ long): The carapace is smooth and narrowed anteriorly, almost triangular in shape as seen from above. The pseudorostrum is about one-fifth as long as the carapace. The antero-lateral and lower margin are convex and antennal notch is obsolete. The first two pairs of peraeopods have the exopod. The carpus of the first peraeopod is stout and one-third as wide as the length which is twice the propodus; its inner margin bears a membranous lamella. The propodus is broad and provided with about seven long but subequal setae. The telson is spindle-shaped, about half as long as the last abdominal segment and bears five pairs of lateral spines, two pairs of lateral hairs and a pair of apical spines. The peduncle of the uropod is twice as long as the telson and longer than the subequal rami. The endopod is three-segmented.

Male (2.2 $\mathrm{mm}$ long): In general the male is very like the female, but the body is somewhat slender; the antero-lateral border of the carapace is deeply sinuated and with a round antero-lateral corner. The antenna is very short. The first three pairs of peraeopods bear the exopod.

Distribution: Onagawa (Miyagi Prefecture), Sagami Bay. Sandy bottom, about 20-30 m.

\section{Gynodiastylis rotundicaudata GAMÔ}

Gynodiastylis rotundicaudata GAMO 1961, p. 106, 109, figs. 3, 4.

Distribution: Sagami Bay (Manazuru), sandy bottom in the shallow depth.

\section{Gynodiastylis nitida HARADA}

Gynodiastylis nitida HSRADA 1962, p. 295, fig. 1.

Distributiom: Sagami Bay (Izu Peninsula), Gunchu-ko (Ehime Prefecture), 10-30 m. 


\section{Gynodiastylis costata CALMAN}

Gynodiastylis costata Calman 1911, p. 372, pl. 36, figs. 1-10.

G. costalus, Stebing 1913, p. 163; Gamó 1962b, p. 206, figs. 39, 40.

Distribution: Kii Peninsula (Shirahama), night surface plankton; the Gulf of Siam, depth 9-37 m.

\section{Gynodiastylis tubicola HARADA}

Gynodiastylis tubicola HARAdA 1961, p. 299, figs. 4-6.

Distribution: Sagami Bay (Izu Peninsula), about $30 \mathrm{~m}$.

\section{Gynodiastylis angicephala HARADA}

Gynodiastylis angicephala HARADA 1961, p. 303, figs. 7, 8.

Distribution: Onagawa Bay (Miyagi Prefecture), Sagami Bay (Izu Peninsula), Gunchu-ko (Ehime Prefecture).

\section{Gynodiastylis bicristata CALMAN}

Gynodiastylis bicristata CALMAN 1911, p. 374, pl. 36, figs. 11-12.

G. bicristatus, StebBing 1913, p. 163.

Distribution: Japan $\left(33^{\circ} 10^{\prime} \mathrm{N}, 129^{\circ} 18^{\prime} \mathrm{E}\right.$, depth $\left.73 \mathrm{~m}\right)$; the Gulf of Siam, 9-18 m.

\section{LITERATURE}

Aizawa, Y., R. Marumo and M. ÔMORI, 1965. On the movement of plankton net in oblique haul. Inform. Bull. planktol. Jap., no. 12, pp. 60-66, figs. 1-7. (In Japanese with English abstract).

Băcescu, M. 1951. Cumacea. Fauna R.P. Române. vol. 4, fasc. 1, pp. 1-91, figs. 1-49. Bucharest. 1961. Deux espèces nouvelles de Makrokylindrus sous-genre Vemakylindrus n. sg. (Crustacés Cumacés) des eaux tropicales du Pacifique (Côte Américaine). Rev. Biol. Acad. Répub. Pop. Roumaine. T. 6, pp. 325-333, 3 figs.

1962. Contribution à la connaissance du genre Makrokylindrus Stebbing (Crustacea

Cumacea). Espèces nouvelles recueillies au cours des campagnes du Lamont Geological Observatory de New York. Abyssal Crustacea. 1, Vema Research Series. pp. 209-223, 7 figs. Columbia Univ. Press. New York.

Bachmayer, F. 1960. Eine fossile Cumaceenart (Cumacea, Malacostraca) aus dem Callovien von la Voulte-sur-Rhône (Ardèche). Ecologae geol. Helvetiae. 53 (1), pp. 422-426, 2 figs. 2 pls.

Barnard, J.L. and R.R. Given. 1961. Morphology and Ecology of some sublittoral cumacean Crustacea of southern California. Pacif. Nat. vol. 2, pp. 154-165, 4 figs.

Bruun, A.F., S. Greve, H. Mielche \& R. Sparch (editers). 1956. The Galathea deep sea expedition, 1950-1952. pp. 1-296. MacMillan. New York.

Calman, W.T. 1904. Report on the Cumacea collected by Prof. Herdman, at Ceylon, in 1902. Ceylon Pearl Oyster Fish., 1904, Suppl. Rep., xii, pp. 159-180, 5 pls. 
1905a. The Marine Fauna of the W'est Coast of Ireland, Part V. Cumacea. Sci. Invest. Fish. Ireland, 1904, app. 1, pp. 3-52, 5 pls.

1905b. The Cumacea of the Siboga Expedition. Siboga-Expeditie, monogr. 36, pp. 1-23, 2 pls., 4 figs.

1907. On new or rare Crustacea of the order Cumacea from the collection of the Copenhagen Museum. Part I. The Families Bodotriidae, Vaunthompsoniidae, and Leuconidae. Trans. Zool. Soc., London. vol. 18, pp. 1-58, 9 pls.

1909. Crustacea in: Lankester, R.: A Teaetise on Zoology. Part 7, (3), pp. 1-346, 149 figs. London.

10.

1910. On Heterocuma sarsi, Miers. Ann. Mag. Nat. Hist., ser. 8, vol. 6, pp. 612-616, pl.

1911. On new or rare Crustacea of the order Cumacea from the collection of the Copenhagen Museum. Part II. The Families Nannastacidae and Diastylidae. Trans. Zool. Soc., London. vol. 18, pp. 311-398, pls. 32-37.

1912. The Crustacea of the order Cumacea in the collection of the United States National Museum. Proc. U.S. Nat. Mus., vol. 41, pp. 603-676, 112 figs.

pls. 19-20.

Derzhavin, A. 1923. Malacostraca der Süsswasser-Gewässer von Kamtchatka. Russ. hydrobiol. z., Bd. 2, pp. 181-194. 7 pls.

1926. The Cumacea of Kamtchatka Expedition. Ibid. Bd. 5, pp. 174-182, pls. 3-6.

Ekman. S. 1955. Zoogeography of the Sea. pp. i-xiv, 1-417, 121 figs. Sidgwick \& Jackson, London.

FAGe, L. 1925. À propos d'une espèce nouvelle du genre Heterocuma. Bull. Mus. Hist. Nat. Paris. T. 30, pp. 364-367, 1 fig.

1929. Cumacés et Leptostracés des campagnes scientifiques de S.A.S. le Prince Albert Ier de Monaceo. Résult. Camp. Monaco. fasc. 77, pp. 1-51, 3 pls.

- 1945. Les Cumacés du plankton nocturne des côtes d'Annam. Arch. Zool. éxp. et gén., T. 84, pp. 165-224, 43 figs.

- 1951. Les Cumacés. Faune de France. T. 54, pp. 1-136. 109 figs. Paul Lechevalier, Paris.

FAxon, G.H. 1936. Notes on the natural history of certain sand dwelling Cumacea. Ann. Mag. Nat. Hist., ser. 10, vol. 17, pp. 377-379, 1 fig.

Gamô, S. 1958. On some species of cumacean Crustacea from Sagami Bay. Zool. Mag., Tokyo. vol. 67 , pp. 383-389, 2 figs.

1960a. Five new species of cumacean Crustacea, Genus Dimorphostylis (Diastylidae) from Sagami Bay. Ibid., vol. 69, pp. 101-111, 8 figs.

1960b. On three new species of cumacean Crustacea genus Campylaspis from Tanabe

Bay, Kii Peninsula. Publ. Seto Mar. Biol. Lab., vol, 8, pp. 153-161, 6 figs.

1960c. Cumacea in: Encyclopedia Zoologica Illustrated in coloures. vol. IV, p. 118, pl. 59. Hokuryu-kan, Tokyo. (In Japanese). 1960d. On six new species of cumacean Crustacea, genus Campylaspis (Nannastacidae) from Japan. Zool. Mag., Tokyo. vol. 69, pp. 369-387, 12 figs.

1961. On two new species of cumacean Crustacea, genus Gynodiastylis (Diastylidae) from Sagami Bay. Ibid., vol. 70, pp. 105-109, 4 figs.

1962a. Two new species of Japanese cumacean Crustacea, Leucon simanensis sp. nov., and

L. varians sp. nov., Ibid., vol. 71, pp. 256-261, 4 figs.

1962b. On the cumacean Crustacea from Tanabe Bay, Kii Peninsula. Publ. Seto Mar. Biol. Lab., vol. 10, pp. 153-210, 40 figs.

1963a. On the cumacean Crustacea obtained from Amami-Ôshima Island, southern

Japan. Sci. Rep. Yokohama Nat. Univ., ser. 2, no. 10, pp. 29-60, 18 figs.

1963b. Review on the order Cumacea, with a list of the species found in Japan. Researches on Crustacea. Cardinological Soc. Japan, Tokyo. No. 1, pp. 73-90, pls. 9-15, 3 figs. (In Japanese with English résumé). 
1964a. A new cumacean Crustacea, Cumella alveata sp. nov., from Sagami Bay. Bull. Biogeo. Soc. Japan. vol. 23, pp. 23-28, 2 figs.

1964b. On some cumacean Crustacea from Sagami Bay, with the description of two new species. Sci. Rep. Yokohama Nat. Univ., sec. 2, no. 11, pp. 17-28, 7 figs.

1964c. Cyclaspis purpurascens sp. nov,, a new cumacean Crustacea from Tanabe Bay, Kii

Peninsula. Publ. Seto Mar. Biol. Lab., vol. 12, pp. 191-200, 4 figs.

1964d. On three new species of Cumacea from the Southern Sea of Japan. Cursatceana. vol. 7, pp. 241-253, 7 figs.

1965a. On three new species of Cumacea, Crustacea from Akkeshi Bay, Publ. Akkeshi

Mar. Biol. Sta., no. 14, pp. 1-21, 10 figs.

1965b. Cumacean Crustacea from Akkeshi Bay, Hokkaido. Publ. Seto Mar. Biol. Lab., vol. 13 , pp. 187-219, 12 figs.

__ 1965c. Cumacea in: New illustrated Encylopedia of the Fauna of Japan. vol. II, pp. 527-536, figs. 688-708. Hokuryu-kan, Tokyo. (In Japanese).

1967a. Notes on the Cumacea from the southern part of the Sea of Japan. Researches on

Crustacea. Carcinological Soc. Japan, Tokyo. No. 3, pp. 26-31, pl. 1. (In Japanese with English résumé).

1967b. Notes on some species of Cumacea (Crustacea, Malacostraca) collected by $R V$ TANSEI MARU from Sagami Bay. Inform. Bull. planktol. Jap., Commemoration Number of Dr. Y. Matsue. pp. 17-24, 2 pls. (In Japanese with English abstract).

Given, R.R. 1961. The cumacean fauna of the southern California continental shelf. I. The family Leuconidae. Bull. S. Calif. Acad. Sci., vol. 60 (3), pp. 130-146, figs. 34-47.

1964. The cumacean fauna of the southern California continental shelf. No. 2. The new family Mesolampropidae. Crustaceana. vol. 7, pp. 284-292, 2 figs.

- 1965. Five collections of Cumacea from the Alaskan Arctic. “Arctica," Journ. Artic Inst. North Amer., vol. 18, pp. 213-229, 6 figs.

Hale, H.M. 1928. Australian Cumacea. Trans. roy. Soc. S. Aust., vol. 52, pp. 31-48, 17 figs.

- 1932. A Cumacea new to South Australia. Rec. S. Aust. Mus., vol. 4, pp. 549-550, 1 fig. 1936a. Three new Cumacea from South Australia. Ibid., vol. 5, pp. 395-403, 6 figs. 1936b. Cumacea from a South Australian Reef. Ibid., vol. 5, pp. 404-438, 23 figs.

1937a. Cumacea and Nebaliacea. B.A.N.Z. Ant. Res. Exped., 1929- '31, Rept. ser. B, IV, 2, pp. 39-55, 14 figs.

1937b. Further notes on the Cumacea of South Australian. Reef. Rec. S. Aust. Mus., vol. 6, pp. 61-74, 9 figs.

1943. Notes on two sand dwelling Cumacea Gephyrocuma and Picrocuma. Ibid., vol. 7, pp.

337-342, 9 figs.

1944a. Australian Cumacea. No. 7. The genus Cyclaspis. Ibid., vol. 8, pp. 63-142, 60 figs.

1944b. Australian Cumacea. No. 8. The family Bodotriidae. Trans. roy Soc. S. Aust., vol. 68, pp. 225-285, 38 figs.

1945a. Australian Cumacea. No. 9. The family Nannastacidae. Rec. S. Aust. Mus., vol. 8, pp. 145-218, 49 figs.

1945b. Australian Cumacea. No. 10. The family Leuconidae. Trans. roy. Soc. S. Aust., vol. 69, pp. 86-94, 6 figs.

1945c. Australian Cumacea. No. 11. The family Diastylidae (part 1) Ibid., vol. 69, pp.

173-211, 26 figs.

1946a. Australian Cumacea. No. 12. The family Diastylidae (part 2). Gynodiastylis and related genera. Rec. S. Aust. Mus., vol. 8, pp. 358-444, 60 figs.

1946b. Australian Cumacea. No. 13. The family Lampropidae. Trans. roy. Soc. Aust., vol. 70, pp. 178-188, 4 figs.

1948. Australian Cumacea. No. 14. Further notes on the genus Cyclaspis. Rec. S. Aust. Mus., vol. 9, pp. 1-42, 12 figs. 


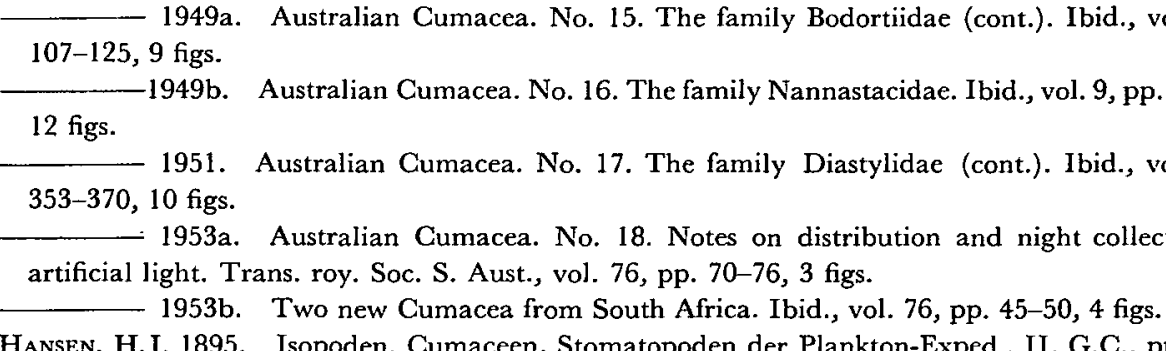

Hansen, H.J. 1895. Isopoden, Cumaceen, Stomatopoden der Plankton-Exped., II, G.C., pp. 1-105, 8 pls.

Anvers.

1908. Schizopoda and Cumacea. Rés. Voyage Belgica, Zoology. pp. 1-21, 3 pls.

1920. Crustacea Malacostraca. IV. Danish Ingolf Exped., vol. 3, pp. 1-86, 4 pls. Copenhagen.

Harada, I. 1959. Gumacean fauna of Japan. I. Family Lampropidae. Jap. Journ. Zool., vol. 12, pp. 229-346, 7 figs.

1960. Cumacean fauna of Japan. II. Family Diastylidae (Part I). Genus Dimorphosiylis. Sci. Rep. Tokyo Kyoiku Daigaku. sect. B, vol. 9, pp. 199-225, 12 figs.

170-175, 4 figs.

1962a. Cumacean Crustacea in the collection of Deep Sea. Annot. zool. Jap., vol. 35, pp.

1962b. Cumacean fauna of Japan. II. Family Diastylidae. 2. Genus Gynodiastylis. Jap. Journ. Zool., vol. 13, pp. 293-306, 8 figs.

1963. On the developmental stages of Cumacea. Zool. Mag., Tokyo. vol. 72, pp. 322323. (In Japanese).

1964. Cumacean fauna of Japan. III. Family Bodotriidae. Pt. 1. Genus Heterocuma Miers and Sympodomma Stebing. Jap. Journ. Zool., vol. 14, pp. 97-104, 3 pls., 3 figs.

HART, J.F.L. 1930. Some Cumacea of the Vancouver Island region. Contr. Canad. Biol., Tronto. (2) 6, pp. 25-40, 5 figs.

Hilgendorf, E. 1894. Ergänzungen betr. die Eocuma hilgendorfi Marcusen. SB. Ges. naturf. Fr. Berlin. 1894, pp. 171-172.

Jones, N.S. 1955. Cumacea of the Bengula Current. Discovery Rep., vol. 27, pp. 279-292, 7 figs.

1956. Cumacea from the West Coast of Africa. "Atlantide" Rep., No. 4, pp. 183-212, 16 figs.

1957. Cumacea. In: Fraser, J.H.: 1958. Fisches d'Identification du Zooplankton. Conseil Permanent International de la Mer. no. 71-76. Copenhagen.

1959. Cumacea from South Africa. Ann. Mag. Nat. Hist., ser. 13, vol. 2, pp. 171-180, 2 figs.

1963. The marine fauna of New Zealand; Crustacea of the order Cumacea. Bull. N.Z.

Dep. Sci. industr. Res., 152, pp. 1-80, 349 figs. (N.Z. Oceanogr. Inst. Mem. No. 23).

Kemp, S. 1916. Cumacea. Fauna of the Chilka-Lake. Mem. Ind. Mus., V, pp. 395-402, 5 figs.

Kurian, C.V. 1951. The Cumacea of Trivancore. Bull. Central. Res. Inst., Univ. Trivancore. ser. C, II, pp. 77-118, 4 pls.

1954. Notes on Cumacea (Sympoda) in the Zoological Survey of India. Rec. Ind. Mus., vol. 52, pp. 275-311, 14 figs.

1965. Cumacea collected by the R.V. Conch during her cruises off the Kerala coast, India, in 1958 and 1959. Crustaceana. vol. 8, pp. 181-189, 21 figs.

Lomakina, N.B. 1955a. Cumacea from Far-east seas. Trav. zool. Acad. Sci. U.S.S.R., T. 18, pp. 112165, 15 figs. (In Russian).

1955b. Cumacea. In: Uschakov, P.: Atlas of Invertebrates of the Far East Seas of the U.S.S.R., pp. 125-137, pl. 27. U.S.S.R. Acad. Sci. Publ. House Moscov. (In Russian). 
1958a. Cumacea of the regions of the Kuril-Sakhalin expedition works. Explor. Far Eastern Seas of U.S.S.R., T. 5, pp. 205-216, 2 figs. (In Russian).

1958b. Cumacea of the Seas of U.S.S.R., pp. 1-310, 201 figs. U.S.S.R. Acad. Sci. Publ. House Moscov. (In Russian).

1960. K. Fauni Cumacea (Crustacea Malacostraca) pribrezhnoe zoni zheltogo mori. Oceanographia et Limonogia Sinica. 3, pp. 94-114. (not seen).

Marcusen, J. 1894. Úber ein neuen Cumaceengenus Eocuma, Fam. Cumidae. aus Japan. SB. Ges. naturf. Fr. Berlin, 1894. pp. 170-171.

Marukawa, H. 1927. Cumacea. In: Illustrated Encyclopedia of the Fauna of Japan. pp. 856-857, figs. 2456-2460. Hokuryu-kan, Tokyo. (In Japanese).

Miers, E.J. 1879. On a collection of Crustacea made by Cap. H.C. Sh. John in the Corean and Japanese Seas. Proc. Zool. Soc., London. 1879. vol. 1, pp. 18-61, 3 pls.

OMORI, M. 1965 . A $160 \mathrm{~cm}$ opening-closing net. I. Description of the gear. Journ. Oceanogr. Soc. Jap., vol. 21, pp. 212-218, 20 figs.

$\longrightarrow$, R. Marumo and Y. Aizawa. 1965. A 160-cm opening-closing net. II. Some notes on the towing behavior of the net. Ibid., vol. 21, pp. 245-252, 4 figs.

Pérès, J.M. 1961. Océanographie biologie et biologie marine. T. 1, pp. 1-541, 35 figs. Univ. de France Press. Paris.

Pike, R.B. and R.F. Le Stueur. 1958. The shore zonation of some Jersey Cuma. Ann. Mag. Nat. Hist., ser. 13, vol. 1, pp. 515-523, 4 figs.

SARs, G.O. 1878-1879. Nye Bidrag til Kundskaben om Middelhavests Invertebratfauna, 2. Arch. Math. Naturv., Bd. 3-4, pp. 1-196, 60 pls.

1887. Report on the Cumacea collected by H.M.S. Challenger during the years 18731886. Rep. Voy. Challenger. Part 55, pp. 1-78, 11 pls.

1899-1900. Cumacea. An account of the Crustacea of Norway, with short descriptions and figures of all the species. vol. 3, pp. i-x, 1-114, 69 pls. Bergen.

Stebing, Th. R.R. 1900. On Crustacea brought by Dr. Willey from the South Sea. Zoological resulat based on material from New Britain, New Guinea, Loyality Island and elswhere collected during the year 1895, 1897 by Dr. WiLley, Pt. V, pp. 605-690, pls. 44-74.

1912. The Sympoda. Ann. S. Afr. Mus., vol. 10, pp. 129-176, 16 pls.

1913. Cumacea (Sympoda). Das Tierreich. Lief. 39, pp. i-xvi, 1-210, 137 figs. Perlin.

Stephensen, K. 1915. Cumacea. Rep. Danish. Oceanogr. Expd., 1908-10. 2, D. 1. pp. 29-34, figs. 16-19.

UÉno, M. 1933. Inland water fauna of the North Kurile Islands. Bull. Biogeo. Soc., Jap. vol. 4, pp. 171-212, pls. 15-18, 18 figs.

1936. Crustacea of the Northern Kurile Island. Ibid., vol. 6, pp. 241-246.

Zenkewitch, L. 1963. Biology of the Seas of the U.S.S.R., pp. 1-995, 841 figs. George Allen \& Unwin. London.

Zimmer, C. 1902. Die von Prof. Dr. Thinelus gesemmelten Cumaceen. Zool. Jahrb., Syst., Bd. 17, pp. 444-456, figs. A-W.

1903. Die Cumaceen des Museums für Naturkunde in Berlin. Ibid., Bd. 18, pp. 665-694, figs. A-Z, AA-EE.

- 1908. Die Cumaceen der Deutschen Tiefsee-Expedition. Wiss. Ergebn. deutsch. Tiefsee Exp. "Valdivia." 1898-1899. Bd. 8, pp. 155-196, pls. 36-46, Jena.

1909. Die Cumaceen der Schwedischen Südpolar-Expedition. Wiss. Ergebn. d. schwed.

Südpol. -Exp. 1901-1903, 6 Lief. 3, pp. 1-31, 8 pls. Stochkolm.

1921a. Eininge neue und weniger bekante Cumaceen des Schwedischen Reichsmuseums.

Ark. Zool., Bd. 13, nr. 21. pp. 1-9, 6 figs.

1921b. Mitteilungen über Cumaceen des Berliner zoologischen Museums. Mitt. Zool.

Mus., Berlin. Bd. 10, pp. 117-149, 55 figs.

1926. Northern and arctic invertebrates in the collection of the Swedish State Museum, 
X. Cumaceen. Vetensk. Akad. Handl,, ser. 3, no. 2, pp. 1-88, 4 pls., 97 figs.

5 figs.

1929. Einige Cumaceen aus russischen Meeren. Expl. Mers URSS. fasc. 9, pp. 61-69,

1930. Untersuchungen an Diastyliden (Ordnung Cumacea). Mitt. Zool. Mus. Berlin. Bd.

16, pp. 583-658, 47 figs.

1936. California Crustacea of the order Cumacea. Proc. U.S. Nat. Mus. vol. 83, pp.

423-439, 39 figs.

- 1937. Pazifischen Cumaceen. Expl. Mers URSS. facs. 23, pp. 38-54. 17 figs.

1940. Die Verbreitung der Cumaceen. Arch. Naturg., (2) Bd. 9, pp. 224-313, 2 figs.

1941. Cumacea. In: Brons's Klassen u. Ordnungen des Tierreich. Bd. 5, Abt. 1, pp. 1-

222, 226 figs. Akad. Verlangs. Leipzig.

1942. Die Gattung Iphinoe. Zool. Anz., Bd. 139, pp. 190-200.

1943. Cumaceen des Stillen Ozeans. Arch. Naturg., Leipzig. (N.F.). Bd. 12, pp. 130-174,

61 figs.

1944. Cumaceen des tropischen Westatlantiks. Zool. Anz., Bd. 144, pp. 121-137, 30 figs.

1952. Indochinesische Cumaceen. Mitt. Zool. Mus. Berlin. Bd. 28, pp. 5-35, 50 figs.

\section{EXPLANATION OF COLOUR PLATE (PLATE XVII)}

Fig. 1. Bodotria biplicata GAMÓ. Female, lateral view, $2.7 \mathrm{~mm}$ long.

Fig. 2. Bodotria serrulata GAMô. Male, lateral view, $4.1 \mathrm{~mm}$ long.

Fig. 3. Bodotria ovalis Gamo. Ovigerous female, lateral view; and anterior portion of body, dorsal view, $4.2 \mathrm{~mm}$ long.

Fig. 4. Cyclaspis purpurascens Gamo. Ovigerous female, lateral view, $2.9 \mathrm{~mm}$ long.

Fig. 5. Nannastacus spinulosus Gamo. Male, lateral view, $1.6 \mathrm{~mm}$ long.

Fig. 6. Schizotrema sakaii GAMô. Ovigerous female, lateral view; and anterior portion of body, dorsal view; $1.1 \mathrm{~mm}$ long.

Fig. 7. Campylaspis reticulata GaMo. Male, lateral view, $2.1 \mathrm{~mm}$ long.

Fig. 8. Lamprops sarsi Derzhavin. Female, lateral view, $3.1 \mathrm{~mm}$ long.

Fig. 9. Disalylopsis dawsoni forma calmani Derzhavin. Female, lateral view, $14.5 \mathrm{~mm}$ long. 
Publ. Seto Mar. Biol. Lab., XVI (3), $1968 . \quad$ PLATE XVIII
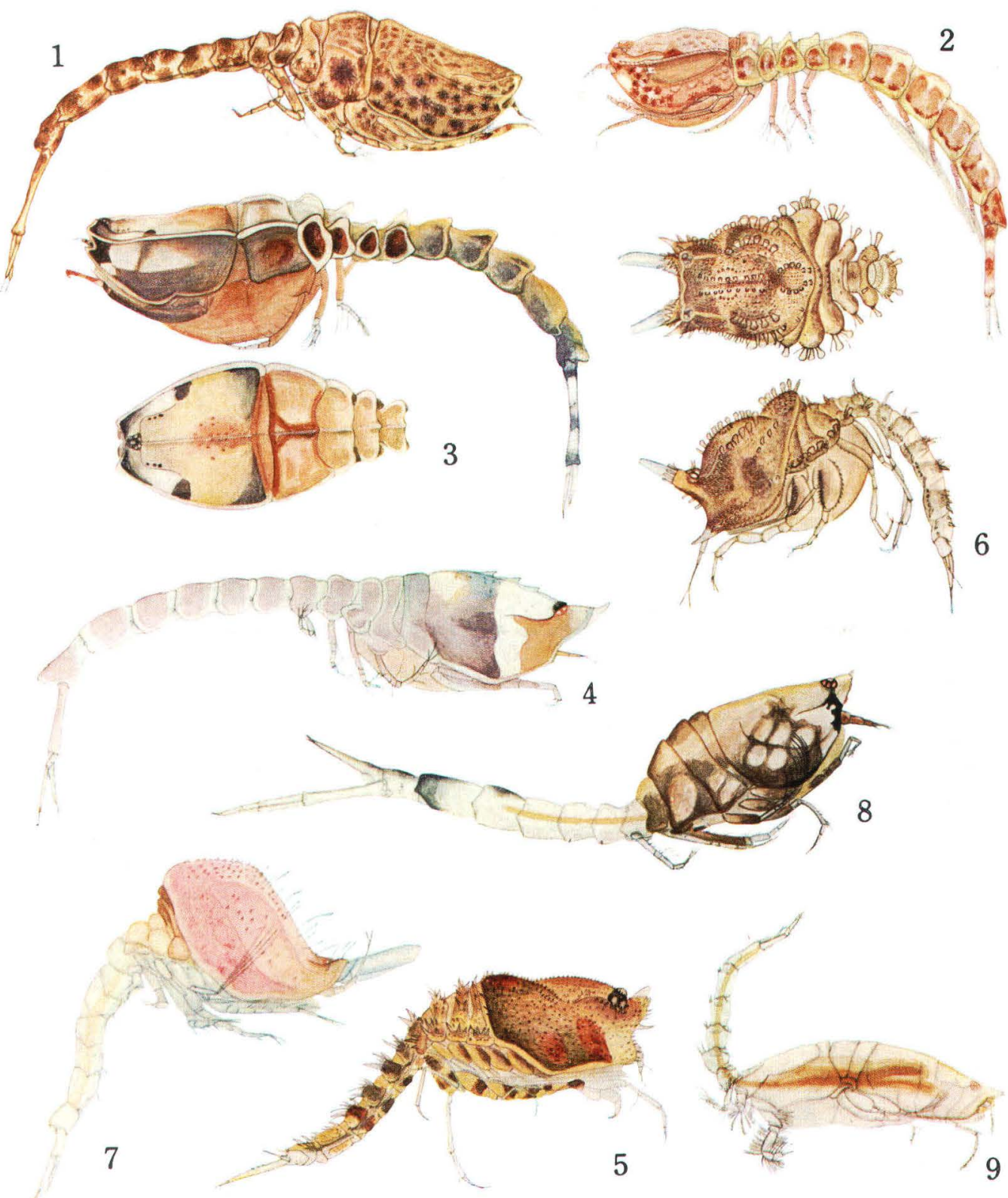

S. GAmô: Cumacea of Japan, Part III 